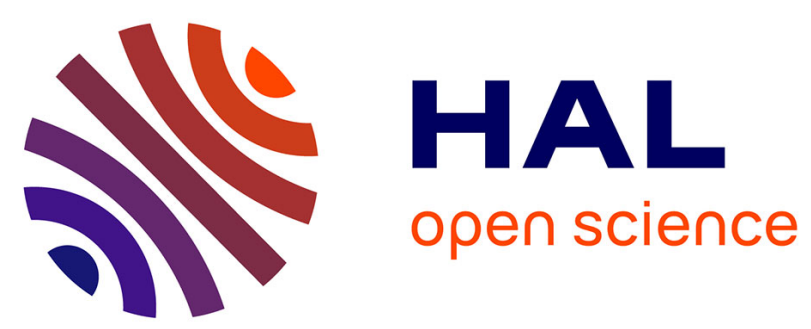

\title{
Role of Glycanation and Convertase Maturation of Soluble Glypican-3 in Inhibiting Proliferation of Hepatocellular Carcinoma Cells
}

Ahmad Saad, Benjamin Liet, Gilles Joucla, Xavier Santarelli, Justine Charpentier, Stephane Claverol, Christophe Grosset, Véronique Trézéguet

\section{To cite this version:}

Ahmad Saad, Benjamin Liet, Gilles Joucla, Xavier Santarelli, Justine Charpentier, et al.. Role of Glycanation and Convertase Maturation of Soluble Glypican-3 in Inhibiting Proliferation of Hepatocellular Carcinoma Cells. Biochemistry, 2018, 57 (7), pp.1201-1211. 10.1021/acs.biochem.7b01208 . inserm-02437926

\section{HAL Id: inserm-02437926 https://www.hal.inserm.fr/inserm-02437926}

Submitted on 14 Jan 2020

HAL is a multi-disciplinary open access archive for the deposit and dissemination of scientific research documents, whether they are published or not. The documents may come from teaching and research institutions in France or abroad, or from public or private research centers.
L'archive ouverte pluridisciplinaire HAL, est destinée au dépôt et à la diffusion de documents scientifiques de niveau recherche, publiés ou non, émanant des établissements d'enseignement et de recherche français ou étrangers, des laboratoires publics ou privés. 


\title{
Role of glycanation and convertase maturation of the soluble Glypican-3 in inhibiting proliferation of hepatocellular carcinoma cells
}

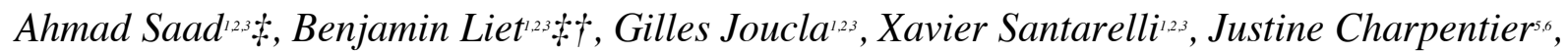 \\ Stéphane Claverol ${ }^{4}$, Christophe Grosset ${ }^{5,6}$, Véronique Trézéguet ${ }^{12.3,55 *}$ \\ Univ. Bordeaux, CBMN, UMR 5248, F-33615, Pessac, France \\ ${ }^{2}$ CNRS, CBMN, UMR 5248, F-33615, Pessac, France \\ ${ }^{3}$ Bordeaux INP, CBMN, UMR 5248, F-33615, Pessac, France \\ ${ }^{4}$ Univ. Bordeaux, Plateforme Protéome, CGFB, F-33076 Bordeaux, France \\ Univ. Bordeaux, Biotherapy of Genetic Inflammatory Diseases and Cancers, U1035, F-33000 \\ Bordeaux, France. \\ INSERM, Biotherapy of Genetic Inflammatory Diseases and Cancers, U1035, F-33000 \\ Bordeaux, France.
}

\begin{abstract}
.
Glypican 3 (GPC3) is a complex heparan sulfate proteoglycan associated with the outer surface of the plasma membrane by a glycosyl-phosphatidylinositol anchor (GPI). It is also Nglycosylated and processed by a furine-like convertase. GPC3 has numerous biological functions. While undetectable in normal liver tissue, it is abnormally and highly overexpressed in hepatocellular carcinoma (HCC). Interestingly, proliferation of HCC cells such as HepG2 and $\mathrm{HuH7}$ is inhibited when they express a soluble form of GPC3 after lentiviral transduction. To get more insight into the role of some of its post-translational modifications, we have designed a mutant GPC3, sGPC3m, without its GPI anchor, convertase cleavage site and glycosaminoglycan chains. The highly pure sGPC $3 \mathrm{~m}$ protein strongly inhibited $\mathrm{HuH} 7$ and HepG 2 cell proliferation in vitro, and induced a significant increase in their cell doubling time. It changed the $\mathrm{HuH} 7$ cell morphology but not that of HepG2. It induced $\mathrm{HuH} 7$ cell nuclear area oversize and adherent cell junction restructuration. Unexpectedly, for both cell types the apoptosis, cell division and the $\beta$-catenin levels were not altered though the growth inhibition was very efficient. Overall, our data show that glycanation and convertase maturation are not required for $\mathrm{sGPC} 3 \mathrm{~m}$ to inhibit $\mathrm{HCC}$ cell proliferation.
\end{abstract}




\section{INTRODUCTION.}

Glypican 3 (GPC3) is a complex heparan-sulfate proteoglycan that plays a crucial role in cell homeostasis and tissue development. Glycosylphosphatidylinositol (GPI) anchors this glycoprotein in the plasma membrane ${ }^{12.3}$. Its role was extended to the control of growth factor/receptor interactions, among which are Wnt, Hedgehog $(\mathrm{Hh})$, bone morphogenetic proteins (BMP) and fibroblast growth factors (FGF). GPC3 acts upstream of these key signaling pathways that are linked to proliferation, differentiation, migration, gene expression, and pathologies such as cancers ${ }^{2,4,5}$. The role of GPC3 in the control of cell biology has been highlighted by "loss-of-function" mutations affecting the GPC3 gene in the X-linked genetic Simpson-Golabi-Behmel Syndrome (SGBS) ${ }^{17}$.

GPC3 is also involved in several cancers in different ways ${ }^{13.5 .7}$. In lung and breast cancers, it acts as a tumor gene suppressor ${ }^{3}$. On the contrary, it is an oncogene in liver tumors, including hepatocellular carcinoma (HCC) and hepatoblastoma, for which GPC3 mRNA and protein are abnormally overexpressed ${ }^{8,10.11}$. In these hepatic tumors, the Wnt pathway is frequently overactivated ${ }^{12,1,3,4,15}$. GPC3 constitutes a highly relevant molecular target and a widely used biomarker (see for examples ${ }^{16,171,1,19}$ ).

These opposite characteristics of GPC3 in cancers could be related to its post-translational modifications (PTM) that could influence its partnership with different soluble ligands and membranous proteins. Those PTM are depicted in Figure 1, where GPC3 is modelled using the atomic structure obtained for the human $\mathrm{GPC}^{20}$. GPC3 follows the secretory pathway and the $\mathrm{N}$-terminal leader peptide is removed after GPC3 has reached the plasma membrane as a GPIanchored protein. The anchor can be cleaved to release soluble GPC3 (sGPC3) in the extracellular matrix. GPC3 can also be proteolyzed by a furin-like convertase between $\mathrm{R}^{355}$ and $\mathrm{R}^{358}$, which generates two fragments of approximately $38 \mathrm{kDa}(\mathrm{N}$-ter fragment) and $22 \mathrm{kDa}(\mathrm{C}$ ter fragment) $)^{21}$. The two peptides remain linked thanks to disulfide bridges established through 14 perfectly conserved cysteines. This processing would be essential for survival of non HCC cells and for Wnt signaling modulation ${ }^{21}$ but not required for HCC cell growth stimulation and Wnt activation ${ }^{22}$. GPC3 is $N$ - and $O$-glycosylated. The attachment sites and composition of $N$ glycans are unknown. The HSGAG chains are linear repeats of variably sulphated disaccharide units (mainly glucuronic acid linked to $N$-acetylglucosamine) attached to $\mathrm{S}^{495}$ and $\mathrm{S}^{509}$ and facilitate Wnt and Hh binding ${ }^{23}$.

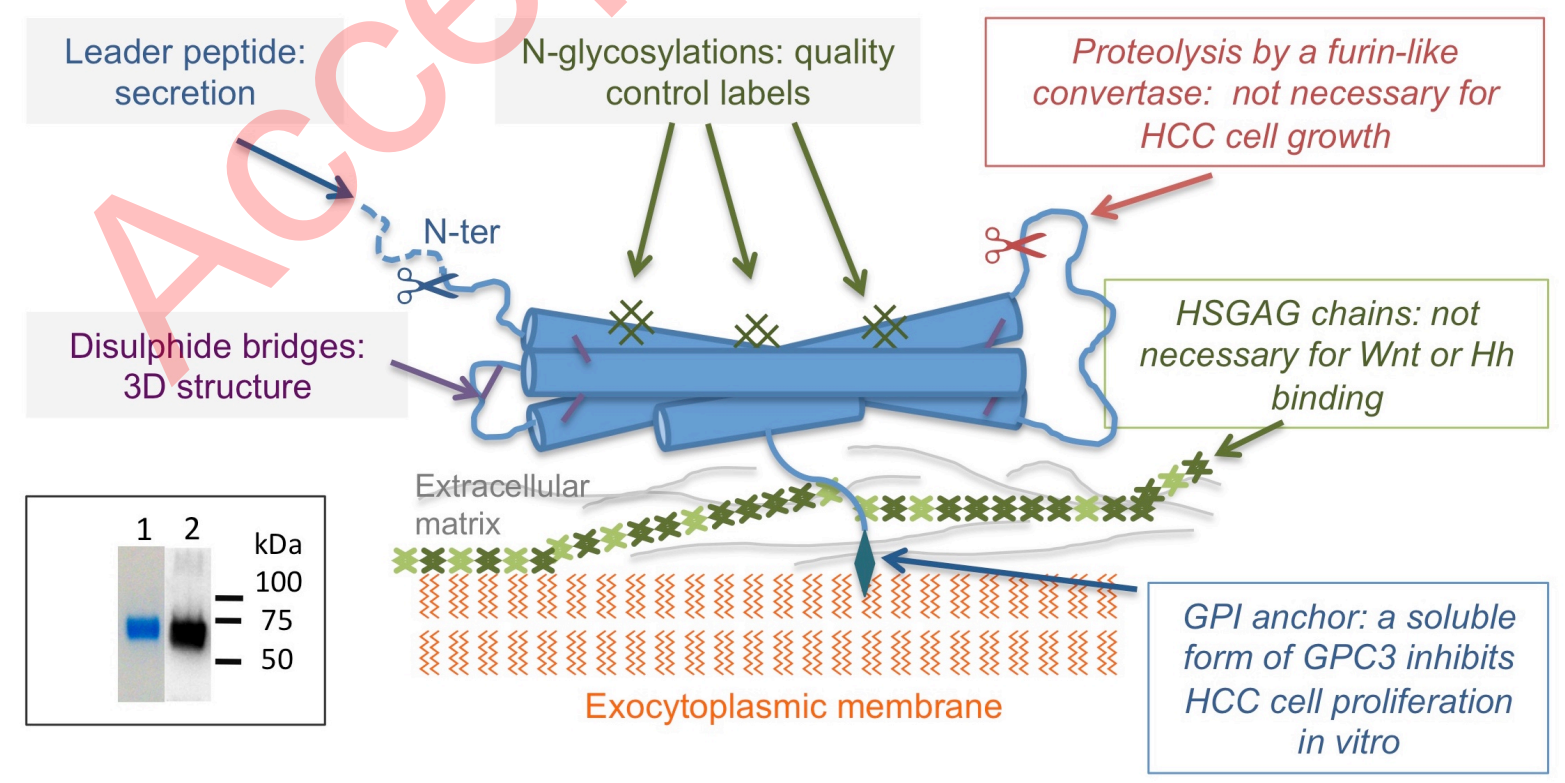


Figure 1: Schematic representation of GPC3. Inset: sGPC3m, after purification by Ni-NTA chromatography, analyzed by SDS-PAGE and (1) Coomassie blue staining or (2) western blotting with anti-GPC3 antibodies from Biomosaics.

Capurro et al..$^{23}$ have shown that GPC3 associates with Wnt ligands and the Frizzled receptors and must be anchored to the membrane to stimulate the Wnt pathway. As a consequence, Zitterman et al.$^{24}$ hypothesized that a soluble form of GPC3 secreted in the extracellular medium would titrate Wnt from the cell surface of HCC cells and thus, prevent Wnt activation and tumoral hepatic cell proliferation. Moreover, they observed that various HCC cells infected with lentiviruses allowing the expression of a soluble GPC3 (sGPC3, no GPI anchor) exhibited a lower proliferation rate ${ }^{24}$. Later on, Feng et al ${ }^{25}$ reported in a short communication that a partially purified recombinant sGPC3 without its last 25 amino acids (sGPC3) decreased HepG2 cell proliferation, thus suggesting that the sGPC3 protein itself mediates this effect.

To clearly establish that the protein itself accounts for the inhibitory effect and investigate more in depth the role of the PTM in this process, we designed a mutant, named sGPC $3 \mathrm{~m}$, devoid of HSGAG chains, GPI anchor and proprotein convertase site. We obtained a highly pure protein and showed that the HSGAG chains and the convertase processing are not requisite to mediate inhibition by sGPC3. Interestingly, we observed no activation of apoptotic mechanisms or cell cycle arrest or important modification of the Wnt/B-catenin pathway. Rather, sGPC $3 \mathrm{~m}$ increased the doubling time and induced important morphological changes of $\mathrm{HuH7}$ cells including an apparent increase in the nuclear area of $20 \%$ and a modification of the cell-cell junctions. Finally, our results clearly state the role of the sGPC3m protein itself in inhibiting HCC cell growth, with no need of HSGAG addition or convertase maturation.

\section{EXPERIMENTAL PROCEDURES.}

Cell lines, plasmid constructs, lentiviral production and titration, and cell transduction

The hepatoma-derived $\mathrm{HuH} 7$ and HepG2 cell lines were cultured in the D-MEM GlutaMAX $^{\mathrm{TM}}$ medium (GIBCO) containing $10 \%$ fetal bovine serum (FBS) supplemented with $100 \mu \mathrm{g} / \mathrm{ml}$ penicillin and streptomycin antibiotics (complete medium) at $37{ }^{\circ} \mathrm{C}$ with $5 \% \mathrm{CO}_{2}$. The sGPC $3 \mathrm{~m}$ encoding gene was chemically synthesized by the GeneScript Company. It was subcloned into the $B a m \mathrm{HI}$ and $\mathrm{XbaI}$ sites of the pL-eGFP-GLO plasmid ${ }^{26}$ to be placed under the control of the long human elongation factor 1 (EF1) alpha promoter. Production and titration of infectious lentiviral particles, as well as biosafety considerations, procedures and policies have been described previously ${ }^{27}$. Lentiviral particles were added to the Gibco ${ }^{\circledR}$ 293-F cells and incubated for $24 \mathrm{~h}$ in the complete medium. The cells were then washed twice with $1 \mathrm{X}$ PBS and adapted to the Freestyle ${ }^{\mathrm{TM}} 293$ expression medium $\left(\mathrm{Gibco}^{\mathrm{TM}}\right)$ medium.

\section{Production and purification of $s G P C 3 m$}

The Gibco® 293-F cells stably expressing sGPC3m were incubated for five days at $37{ }^{\circ} \mathrm{C}$ with $8 \% \mathrm{CO}_{2}$ in the Freestyle ${ }^{\mathrm{TM}} 293$ expression medium $\left(\mathrm{Gibco}^{\mathrm{TM}}\right)$. After the cells were centrifuged, the culture medium was equilibrated with $350 \mathrm{mM} \mathrm{NaCl}$ in Buffer A $(50 \mathrm{mM}$ $\mathrm{NH}_{4} \mathrm{HCO}_{3} \mathrm{pH} 7.5,5 \%$ methanol). After loading, the Ni-NTA (nickel-nitrilotriacetic acid) resin $\left(\right.$ QIAGEN $^{\circledR}$ ) was washed with $350 \mathrm{mM} \mathrm{NaCl}$ in Buffer A, then with $150 \mathrm{mM} \mathrm{NaCl}$ in Buffer A. sGPC $3 \mathrm{~m}$ was eluted with a linear gradient from $100 \%$ of buffer A containing $50 \mathrm{mM} \mathrm{NaCl}$ to $50 \%$ of buffer $\mathrm{B}\left(50 \mathrm{mM} \mathrm{NH} \mathrm{CH}_{3} \mathrm{COOH} \mathrm{pH} 4.5,50 \mathrm{mM} \mathrm{NaCl}\right.$ and $5 \%$ methanol). The fractions containing sGPC $3 \mathrm{~m}$ were pooled and concentrated in Buffer $\mathrm{C}(150 \mathrm{mM} \mathrm{NaCl}$ in Buffer A) and in Vivaspin ${ }^{\circledR}$ 15R units from Sartorius (MMCO: 10,000 Da). The protein concentration was calculated with the molar absorption coefficient at $280 \mathrm{~nm}, \varepsilon=54,290 \mathrm{M}$ 
${ }^{1} \times \mathrm{cm}^{-1}$ or $0.85 \mathrm{ml} \times \mathrm{mg}^{-1} \times \mathrm{cm}^{-1}$, which was deduced from the sGPC $3 \mathrm{~m}$ content in tyrosine, tryptophan and cystine, according to Pace et al..$^{28}$.

\section{Mass spectrometry analyses}

Purified sGPC3m was digested with five different proteases i.e. tryspin (Sigma), chymotrypsin, GluC, elastase and thermolysin (Promega). The resulting peptides were analyzed by LC-MS/MS on a Q-Exactive (Thermo Fisher Scientific, San Jose, CA) mass spectrometer. Data were searched through Proteome Discoverer 2.1 using Sequest as database search engine. Byonic (ProteinMetrics) was also used for intact glycopeptide detection.

\section{Cell proliferation inhibition assays}

20,000 to $50,000 \mathrm{cell} / \mathrm{ml}$ were incubated in the complete medium to which was added Buffer $\mathrm{C}(<5 \%$ of total volume) containing sGPC $3 \mathrm{~m}(5$ to $40 \mu \mathrm{g} / \mathrm{ml})$ or not (control). After one to six days of growth, cells were trypsinized and counted. The percentage of proliferation $(\%$ of control) was the ratio of the number of cells counted in the presence of sGPC $3 \mathrm{~m}\left(\mathrm{~N}_{\mathrm{scos}(\mathrm{s})}\right)$ to the number of cells counted in the absence of sGPC $3 \mathrm{~m}\left(\mathrm{~N}_{\mathrm{c}}\right)$ for a given day: \% proliferation $=100$ $\times \mathrm{N}_{\mathrm{sPCO}_{3} /} / \mathrm{N}_{\mathrm{c}}$. The proliferation inhibition was I $(\%)=100 \times\left(1-\left(\mathrm{N}_{\mathrm{scres}_{m}} / \mathrm{N}_{\mathrm{c}}\right)\right)$. The inhibition curve as a function of time was analyzed as a first order process: $\mathrm{I}=\mathrm{I}_{\text {мax }}\left(1-\mathrm{e}^{\mathrm{kn}}\right)$, where $\mathrm{I}$ is the percentage of proliferation inhibition, $I_{m a x}$ the maximum of inhibition, $k$, the first order kinetic constant, and $\mathrm{t}$ the number of incubation days. The inhibition curve as a function of sGPC $3 \mathrm{~m}$ concentration was analyzed with a model of a single class of binding site for sGPC $3 \mathrm{~m}: \mathrm{I}=\mathrm{I}_{\mathrm{Max}} \times[\mathrm{sGPC} 3 \mathrm{~m}] /\left(\mathrm{IC}_{\mathrm{s} o}\right.$ $+[\mathrm{sGPC} 3 \mathrm{~m}]$ ), where $\mathrm{I}$ is the percentage of inhibition, $\mathrm{IC}_{50}$ the concentration inducing half of the maximum of inhibition $\left(\mathrm{I}_{\mathrm{Ma}}\right)$ and $[\mathrm{sGPC} 3 \mathrm{~m}$ ] the inhibitor concentration.

\section{Cell biomass}

Cell biomass was measured with the Sulforhodamine B based In vitro Toxicology Assay Kit (Sigma) according to the manufacturer's instructions. The dye binds to cellular proteins and is then solubilized in a base. The absorbance of the dye is measured at a wavelength of $565 \mathrm{~nm}$ and is proportional to the cell biomass of viable cells.

\section{Flow cytometry}

Cells $(50,000 / \mathrm{ml})$ were grown in the complete medium in the absence (control) or in the presence of sGPC $3 \mathrm{~m}(20 \mu \mathrm{g} / \mathrm{ml})$ for four days. The apoptotic and necrotic cells were identified with the PE Annexin V Apoptosis Detection Kit I from BD Pharmingen according to the manufacturer recommendation. The proportions of cells in each part of the cell cycle were determined with the BrdU Flow kit from BD Pharmingen. Cells were then analyzed with a Fluorescence-activated cell sorter (BD FACSCanto II) and the BD FACSDiva software.

\section{Hoechst staining}

Nuclear DNA was visualized by Hoechst staining. HuH7 cells were seeded on sterile coverslips in 12-well plates containing the complete medium to which was added buffer $\mathrm{C}$ alone (control) or supplemented with 20 or $30 \mu \mathrm{g} / \mathrm{ml} \mathrm{sGPC} 3 \mathrm{~m}$. After four days of growth, the cells were fixed for 10 min with $4 \%$ paraformaldehyde, washed twice with PBS, and stained with Hoechst $33258(1 / 1000)$ for $5 \mathrm{~min}$ at room temperature. The stained cells were washed twice with PBS. The coverslips were mounted with $10 \mu 1$ of Dako ${ }^{\circledast}$ medium and were examined under a fluorescence microscope (Nikon). The captured images were analyzed with the ImageJ software (National Institutes of Health) to estimate the nuclear DNA area. At least 120 (control) or 210 (sGPC3m) cells were analyzed. 


\section{Cell extracts}

Cells were lysed with the cell lysis buffer from Cell Signaling Technology in the presence of the cOmplete ${ }^{\mathrm{TM}}$ ULTRA, EDTA-free Protease Inhibitor Cocktail and the PhosSTOP ${ }^{\mathrm{TM}}$ phosphatase inhibitor from Roche. After a brief sonication on ice and centrifugation at $4^{\circ} \mathrm{C}$, the protein concentration in the supernatant was determined with the Bicinchoninic Acid reagent from Sigma.

\section{Antibodies, cell immunostaining and western blot analyses}

Whole cell extracts (40 $\mu \mathrm{g}$ of proteins/lane) were loaded on a 4-20\% SDS-PAGE. After blotting, the nitrocellulose membranes (GE Healthcare) were saturated with $5 \%$ bovine serum albumin in PBS-Tween and successively incubated with the indicated primary antibodies and the adequate horseradish peroxidase-coupled or fluorescent secondary antibodies. Enhanced chemiluminescence signals were detected using the GeneGnome XRQ from Syngene and quantified using the ImageJ software. Anti-GPC3 antibodies were from Biomosaics, antipentaHis from GE-Healthcare, anti-FN1, anti-Wnt3a and anti- $\beta$-catenin were from R\&D Systems, anti-E-cadherin from BD Biosciences, anti-ZO-1 from Invitrogen, anti Akt, Erk, pAkt and pErk from Cell Signaling Technology and anti-actin from Sigma. Blots decorated with fluorescent secondary antibodies were analyzed with the Odyssey system (Li-Cor Biosciences). After blotting, membranes were stained with SYPRO Ruby Protein Blot Stain (Invitrogen) and scanned with the Molecular Imager PharosFX (Bio-Rad) for the quantification of protein loading. Specific antibody signals were normalized on total protein amount on each entire lane or on actin content for each lane.

For immunofluorescence studies, cells were grown on microscope coverslips, rinsed with PBS, fixed with $4 \%$ paraformaldehyde and permeabilized with $0.2 \%$ Triton-X100, treated with the primary antibody and then with the fluorescent secondary antibody. Coverslips were counterstained with DAPI and mounted in Fluoromount-G (Molecular Probes) before observation and photo capture under an epifluorescence microscope (magnification $\times 63$ ) or a confocal microscope.

Statistical analyses

All analyses were done using GraphPad Prism 7.0 software. Data are represented as mean with standard deviation (SD) from at least three independent experiments. When experiment contained three groups of values or more, regular two-way analysis of variance (ANOVA) was used for the comparison of multiple means. Means were considered significantly different if pvalue $<0.05$. The ANOVA test was followed by a Bonferroni's multiple-comparison post-test and all data or selected pairs of data were compared. Two groups of values were compared with an unpaired T-test. 


\section{RESULTS.}

Design, production and purification of $s G P C 3 m$

We designed a gene encoding a soluble form of GPC3, sGPC3m, of which the GPI attachment sequence was replaced with the TEV protease recognition and cleavage sites, followed by a stretch of 6 histidines. Both HSGAG attachments sites ( $S^{455}$ and $S^{5 * 9}$ ) were mutated into alanines. GPC3 is proteolyzed by a furin-like convertase. This process is partial in vivo and dispensable to some GPC3 functions ${ }^{22}$. Hippo et al.$^{29}$ identified the proteolytic site as being between $\mathrm{R}^{358}$ and $\mathrm{S}^{3{ }^{39}}$. Both arginines of the recognition site $\left(\mathrm{R}^{355}-\mathrm{Q}-\mathrm{Y}-\mathrm{R}^{338}\right)$ were mutated into alanines.

sGPC3m was purified from the culture media of the stably transduced 293-F cells. A gradient of $\mathrm{pH}$ and imidazole applied on the Ni-NTA columns eluted two peaks (data not shown). The first one, at around $\mathrm{pH} \mathrm{6.5,} \mathrm{had} \mathrm{a} \mathrm{higher} \mathrm{absorbance} \mathrm{at} 254 \mathrm{~nm}$ than at $280 \mathrm{~nm}$ and contained virtually no sGPC $3 \mathrm{~m}$, which was eluted in the second peak. The whole fraction corresponding to peak 2 exhibited a pH value of around 5 and the absorbance at $280 \mathrm{~nm}$ was higher than at $254 \mathrm{~nm}$. The fractions for each peak were pooled and concentrated. As shown by SDS-PAGE analyses, the second peak contained highly pure sGPC $3 \mathrm{~m}$, whose electrophoretic migration corresponded to an apparent molecular mass comprised between 50 and $75 \mathrm{kDa}$ (Figure 1 , inset), consistent with the expected molecular mass $(63,500 \mathrm{kDa})$ for the protein core. The apparent $\mathrm{pI}$ was estimated from isoelectrofocalisation analyses and was around 6 . This value is close to 5.1, which corresponds to the calculated $\mathrm{pI}$ of the non-glycanated protein.

sGPC $3 \mathrm{~m}$ was further characterized by mass spectrometry. The results confirmed the high degree of purity of the protein preparation $(99.5 \%)$. We could clearly identify three Nglycosylation sites: $\mathrm{Asn}^{124}, \mathrm{Asn}^{241}$ and $\mathrm{Asn}^{418}$. The glycosyl composition was much more heterogenous for $\mathrm{Asn}^{124}$ and $\mathrm{Asn}^{241}$ than for $\mathrm{Asn}^{418}$ (Supplementary Table S1), but the precise assembly was not elucidated. The GPC3 leader sequence corresponds to the first 24 amino acids. Finally, the $N$-terminus of the mature protein was identified as a pyroglutamate, which corresponded to the cyclization of $\mathrm{Gln}^{25}$.

\section{Externally added $s G P C 3 m$ inhibits tumor cell proliferation}

We evaluated the inhibitory properties of the pure sGPC3m on HCC cell growth. We first compared $\mathrm{HuH} 7$ proliferation without or with $20 \mu \mathrm{g} / \mathrm{ml}$ of sGPC3m during six days (Figure 2A) and observed a significant reduction in the cell number in the presence of sGPC $3 \mathrm{~m}$ suggesting that $\mathrm{sGPC} 3 \mathrm{~m}$ induced proliferation inhibition. After four days, the treated cell exhibited more heterogeneous morphology than the untreated cells: some were bigger, others more elongated and the number and area of nuclei were variable (Figure 2B). The proliferation inhibition increased with incubation duration and reached a plateau after four to five days (Figure 2C) with $\mathrm{I}_{\text {Max }}=56 \pm 3 \%$ in the presence of $20 \mu \mathrm{g} / \mathrm{ml} \mathrm{sGPC} 3 \mathrm{~m}$. The reaction rate coefficient was $\mathrm{k}=0.68 \pm 0.14 \mathrm{~d}^{-1}$. The generation time, calculated from the proliferation rate after four days of growth, was $1.5 \pm 0.2$ days for the control cells and was increased to $2.3 \pm$ 0.35 days and $4.4 \pm 0.4$ days in the presence of $20 \mu \mathrm{g} / \mathrm{ml}$ and $30 \mu \mathrm{g} / \mathrm{ml}$ of sGPC $3 \mathrm{~m}$, respectively (Figure 2D). We checked that the externally added sGPC $3 \mathrm{~m}$ was stable during the incubation with $\mathrm{HuH7}$ cells by analyzing the culture media, after one, five and six days of growth, by SDSPAGE and immunodetection with antibodies directed against GPC3 or the polyhistidine tag. No proteolytic degradation was observed even after six days (data not shown). 

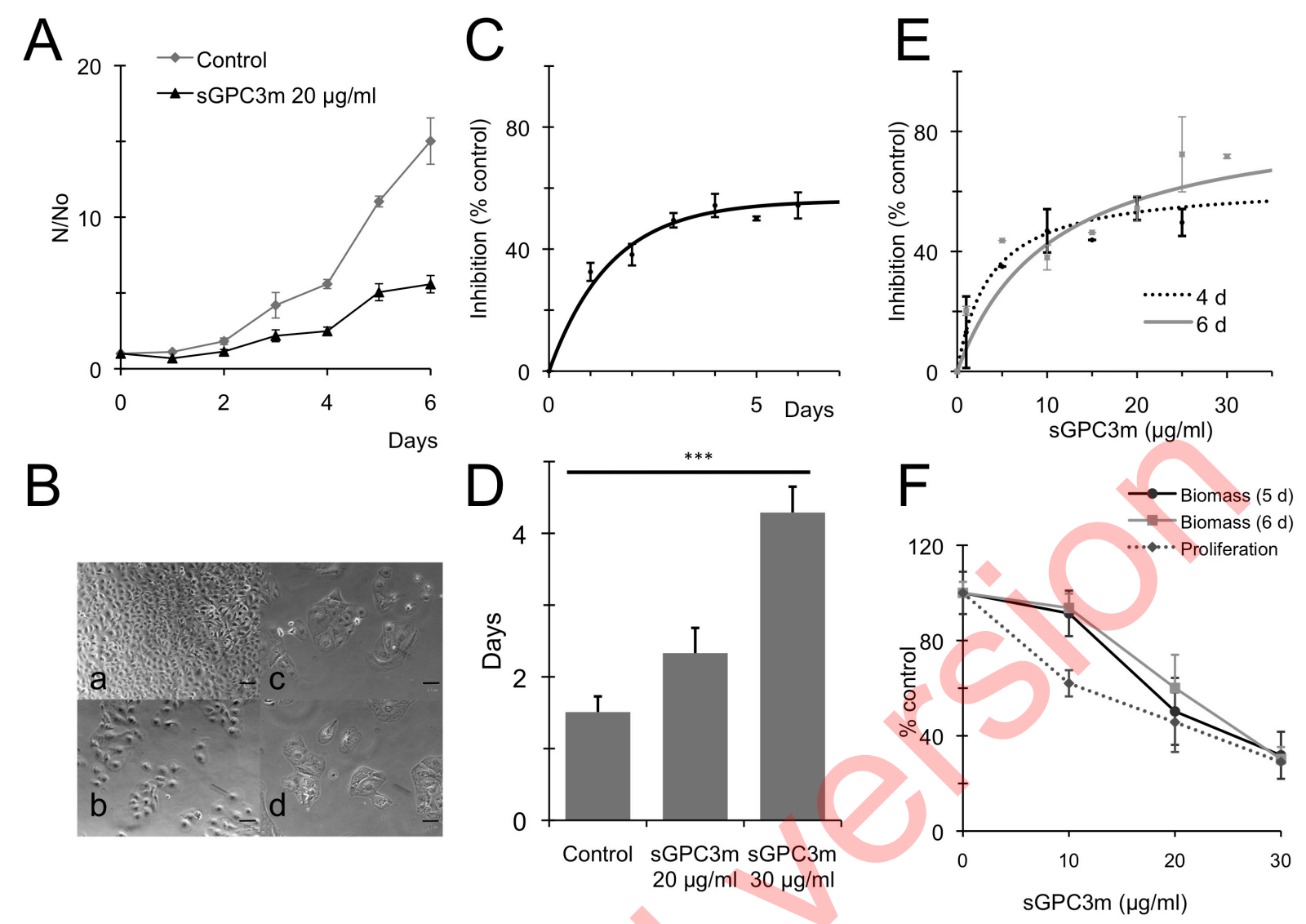

Figure 2: Inhibition of $\mathrm{HuH7}$ cell proliferation by externally added sGPC3m. HuH7 cells $(20,000-50,000 / \mathrm{ml})$ were incubated for up to six days with $20 \mu \mathrm{g} / \mathrm{ml}$ (A-D) or variable amounts of sGPC3m $(E, F)$. A) N/No corresponds to the ratio between $\mathrm{N}$ the number of cells at the indicated time and No the number of cells inoculated at $t=0$. B) HuH7 cells $(20,000 / \mathrm{ml})$ were incubated without (a) or with sGPC $3 \mathrm{~m}$ (b, c, d). Cells were photographed after six days under a microscope with a 10X lens. The bar stands for $200 \mu \mathrm{m}$. The different panels represent different fields under the microscope and they underline the heterogeneity of the cell morphology in the presence of sGPC $3 \mathrm{~m}$. C) Kinetics of inhibition in the presence of $20 \mu \mathrm{g} / \mathrm{ml}$ sGPC $3 \mathrm{~m}$. The proliferation (\% of the control) was the ratio of the number of cells counted in the presence $\left(\mathrm{N}_{\text {soresm }}\right)$ and the number of cells counted in the absence of sGPC $3 \mathrm{~m}\left(\mathrm{~N}_{\mathrm{c}}\right)$ for a given day: proliferation $(\%$ control $)=100 \times \mathrm{N}_{\mathrm{sorem} n} / \mathrm{N}_{\mathrm{c}}$. The inhibition of proliferation was $(\%)=100$ $\times\left(1-\left(\mathrm{N}_{\text {sсres }} / \mathrm{N}_{\mathrm{c}}\right)\right)$. D) The doubling time $\mathrm{t}_{2 \mathrm{n}}$ was calculated after four days of growth, without (Control) or with $20 \mu \mathrm{g} / \mathrm{ml} \mathrm{sGPC} 3 \mathrm{~m}$ using $\mathrm{t}_{2 \mathrm{n}}=\mathrm{t} \times \ln (2) / \ln (\mathrm{N} / \mathrm{No})$. $* * * \mathrm{p}<0.001$. E) Kinetics of inhibition after four (dotted line) and six days (continuous line) of growth in the presence of variable amounts of sGPC $3 \mathrm{~m}$. F) HuH7 cells $(20,000 / \mathrm{ml})$ were incubated for five or six days without or with variable amounts of $\operatorname{sGPC} 3 \mathrm{~m}(10,20,30 \mu \mathrm{g} / \mathrm{ml})$. Cell biomass was measured by sulforhodamine B staining after five and six days and compared to the percentage of proliferation after six days.

The sGPC3m-mediated proliferation inhibition on $\mathrm{HuH7}$ cells was concentration-dependent after two (Figure S1), four and six days of growth (Figure 2E). We analyzed the data with a model of a single class of binding site for sGPC $3 \mathrm{~m}$ (see Materials and Methods). $\mathrm{I}_{\max }$ was $55 \pm$ $13 \%, 63 \pm 7$ and $87 \pm 22 \%$ after two, four and six days of growth, respectively. The mean $\mathrm{IC}_{s 0}$ value was $8 \pm 2 \mu \mathrm{g} / \mathrm{ml}(120 \pm 33 \mathrm{nM})$. 
The cell biomass, which reflects the cell growth, was measured after five or six days in the absence or presence of 10,20 or $30 \mu \mathrm{g} / \mathrm{ml}$ of sGPC $3 \mathrm{~m}$ and compared to $\mathrm{HuH} 7$ cell proliferation after 6 days of growth (Figure 2F). The decrease in biomass roughly followed the decrease in proliferation, except in the presence of $10 \mu \mathrm{g} / \mathrm{ml} \mathrm{sGPC} 3 \mathrm{~m}$, which is close to the $\mathrm{IC}_{s 0}$ (see above). In this case, the biomass was not significantly different from that of the control.

We then investigated the inhibition properties of sGPC $3 \mathrm{~m}$ on the hepatoblastoma cells HepG2 because they express GPC3 at a higher level than $\mathrm{HuH} 7$ cells $^{24}$. We observed a significant proliferation inhibition (Figure 3A) reaching $71 \pm 11 \%$ after seven days of growth in the presence of $30 \mu \mathrm{g} / \mathrm{ml} \mathrm{sGPC} 3 \mathrm{~m}$. The maximum of inhibition could not be calculated precisely and the $\mathrm{IC}_{50}$ value was roughly estimated to be around $16 \mu \mathrm{g} / \mathrm{ml}(250 \mathrm{nM})$. The doubling time increased from $1.9 \pm 0.1$ days in the absence of sGPC $3 \mathrm{~m}$ to $2.5 \pm 0.2$ days and 4 \pm 0.8 days in the presence of $20 \mu \mathrm{g} / \mathrm{ml}$ and $30 \mu \mathrm{g} / \mathrm{ml}$ of sGPC $3 \mathrm{~m}$, respectively (Figure 3B). Contrarily to what was observed with the $\mathrm{HuH} 7$ cells, which exhibit an epithelial phenotype, added sGPC3m did not induce morphological changes of the HepG2 cells (Figure 3C), which kept growing in small clusters. Noticeably, the transformed human embryonic kidney cells HEK293T, which do not express detectable levels of GPC3, were not affected by sGPC3m treatment while the human breast cancer cells, MCF-7, were moderately and transiently inhibited (around $30 \%$ after four days) (Data not shown). As for the HuH7 cells, the HepG2 cell biomass was reduced along with the proliferation and the amount of added sGPC3m (Figure 3D). In the end, for the investigated HCC cells, the decrease in biomass could possibly arise from cell death or cell cycle arrest induced by the externally added sGPC3m.
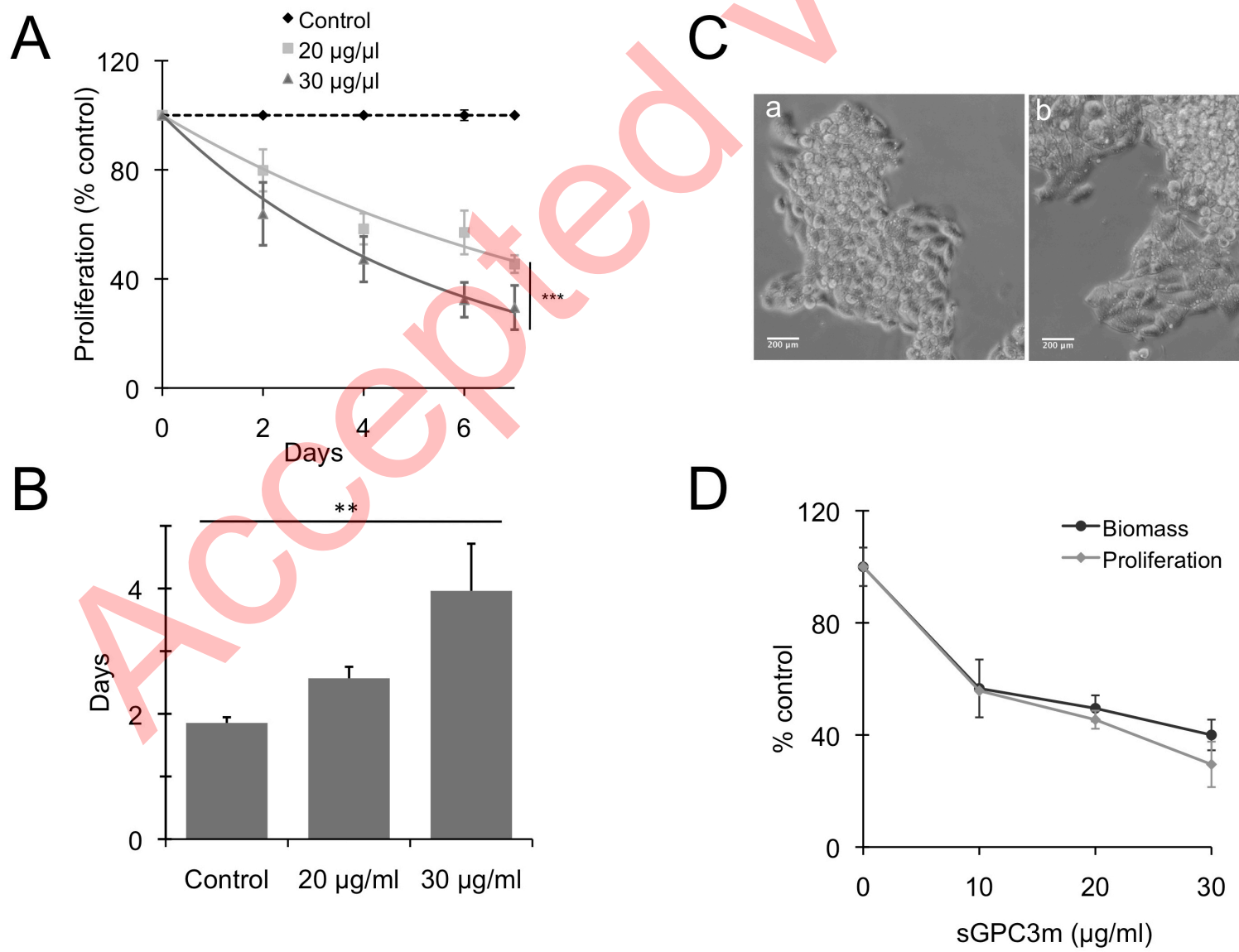

Figure 3: sGPC3m inhibits HepG2 proliferation. A-D) HepG2 cells $(20,000 / \mathrm{ml})$ were incubated without (control) or with sGPC $3 \mathrm{~m}(20$ and $30 \mu \mathrm{g} / \mathrm{ml})$ for up to seven days. The percentage of proliferation was calculated from the comparison with the control cells $(100 \times$ 
$\mathrm{N} /$ No). $\left.*^{* *}, \mathrm{p}<0.001 . \mathrm{B}\right)$ The doubling time was calculated as in the legend of Figure 2.**, $\mathrm{p}<0.01$. C) HepG2 cells $(20,000 / \mathrm{ml})$ were incubated for six days without (control) or with 20 $\mu \mathrm{g} / \mathrm{ml} \mathrm{sGPC} 3 \mathrm{~m}$ and photographed under a microscope. The white bar stands for $200 \mu \mathrm{m}$. C) HepG2 cells $(20,000 / \mathrm{ml})$ were incubated with variable amounts of sGPC $3 \mathrm{~m}$ and incubated for six days. The proliferation and biomass rates were determined as described in the Figure 2 legend.

Then we compared different ways of adding the inhibitor to the cell cultures. HuH7 cells $(20,000 / \mathrm{ml})$ were incubated without or with $20 \mu \mathrm{g} / \mathrm{ml} \mathrm{sGPC} 3 \mathrm{~m}$ and after two days of growth, either the incubation was continued (dotted line) or $20 \mu \mathrm{g} / \mathrm{ml} \mathrm{sGPC} 3 \mathrm{~m}$ were added daily to the medium (increments, dashed line) or the medium was daily replaced with fresh medium containing $20 \mu \mathrm{g} / \mathrm{ml} \mathrm{sGPC} 3 \mathrm{~m}$ (renewal, solid line) (Figure 4). As expected, growth proliferation in the presence of $20 \mu \mathrm{g} / \mathrm{ml}$ reached a plateau of around $55 \pm 8 \%$ after five days. Interestingly, upon the daily addition of $20 \mu \mathrm{g} / \mathrm{ml} \mathrm{sGPC} 3 \mathrm{~m}$ the level of proliferation decreased to around $25 \pm 2 \%$ after five days. At that time the concentration of sGPC $3 \mathrm{~m}$ was $80 \mu \mathrm{g} / \mathrm{ml}$. When the culture medium was replaced with fresh medium containing $20 \mu \mathrm{g} / \mathrm{ml}$ sGPC $3 \mathrm{~m}$, we observed the same pattern of inhibition as the daily addition of $20 \mu \mathrm{g} / \mathrm{ml} \mathrm{sGPC} 3 \mathrm{~m}$ (Figure 4, Renewal), suggesting that a new fraction of the cells was inhibited, similarly to what was observed after progressive addition of sGPC3m (Figure 4, Increments). The inhibitory effect was not linked to the addition of fresh medium since both proliferation curves (Increments and Renewal) were similar. These results suggested that a fraction of sGPC3m remained tightly associated with the cells, in one way or another, to exert a stable inhibition.

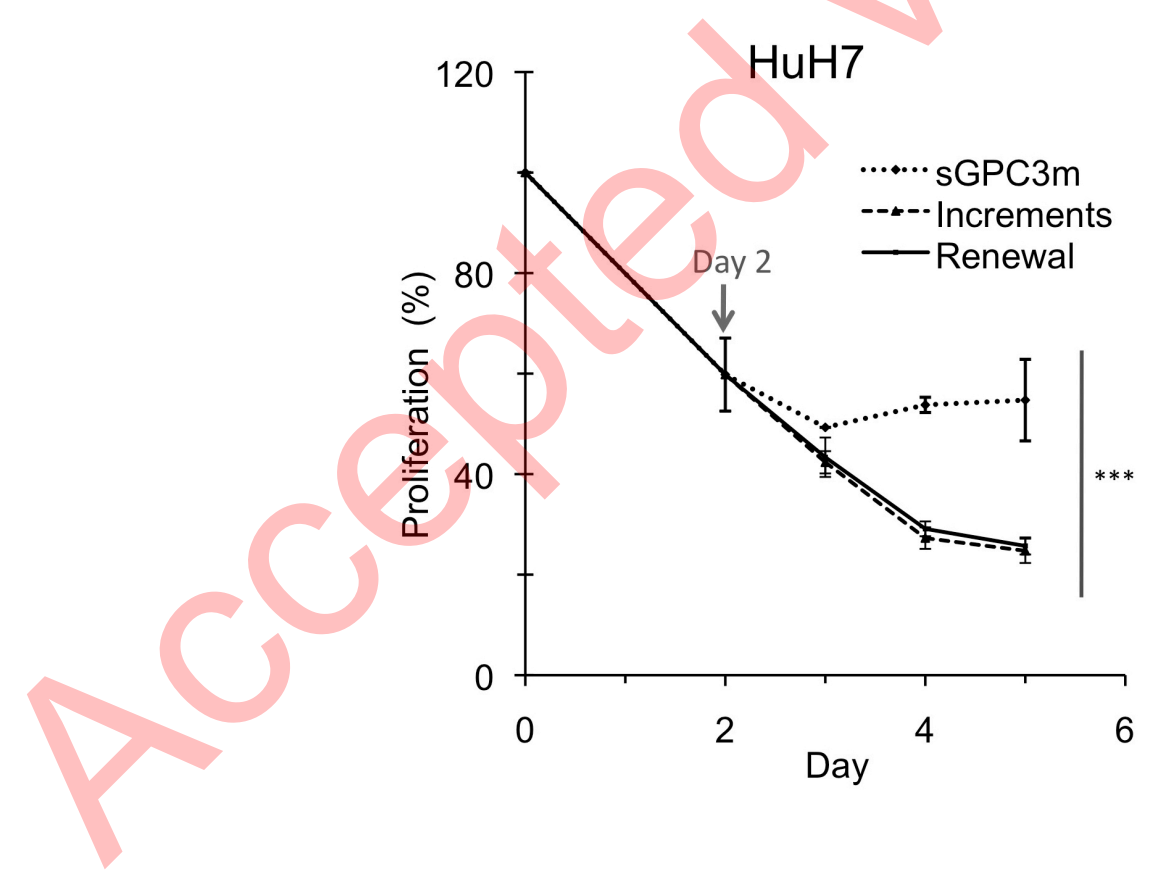

Figure 4: The proliferation inhibition is increased by sGPC3 increments or renewal of the culture medium. HuH7 cells $(20,000 / \mathrm{ml})$ were incubated without or with sGPC3m $(20 \mu \mathrm{g} / \mathrm{ml})$. After two days, the incubation was continued (dotted line) or $20 \mu \mathrm{g} / \mathrm{ml}$ of sGPC3 were added every day (Increments, dashed line) or the growth medium was replaced every day with fresh medium containing $20 \mu \mathrm{g} / \mathrm{ml} \mathrm{sGPC} 3 \mathrm{~m}$ (Renewal, solid line). ***, $\mathrm{p}<0.0001$. 
Externally added sGPC3m modifies the nuclear area size and distribution of HuH7 cells, but does not induce apoptosis, necrosis or changes in cell cycle of HCC cells

As shown in Figure 2B, we noticed that after six days of growth in the presence of sGPC $3 \mathrm{~m}$, HuH7's morphology changed as opposed to untreated cells. Some cells became larger or longer, exhibiting a bigger nucleus or two or more nuclei. HuH7's nuclei were visualized using Hoechst staining after four days of growth without (control) or with 20 or $30 \mu \mathrm{g} / \mathrm{ml} \mathrm{sGPC} 3 \mathrm{~m}$ (Figure $5 \mathrm{~A}$ ). The untreated $\mathrm{HuH7}$ cells exhibited regularly shaped DNA areas while in the presence of sGPC $3 \mathrm{~m}$, we observed binucleated or polynucleated cells, with uneven shapes and areas. The cell-permeable dye Hoechst 33258 binds to the minor groove of double-stranded DNA in living or fixed cells. This can give an estimate of the nuclear area size, by assimilating the fluorescent regions to particles, which we measured with the ImageJ software (Figure 5B). The mean particle areas of the control cells $(0.59 \pm 0.14 \mathrm{AU}$, arbitrary unit) were significantly different from the cells treated with sGPC $3 \mathrm{~m}(0.71 \pm 0.22$ and $0.71 \pm 0.25$ for 20 and $30 \mu \mathrm{g} / \mathrm{ml}$, respectively). Moreover, the particle area distribution varied depending on the sGPC $3 \mathrm{~m}$ concentration. Indeed, for the control cells, it was almost Gaussian and distributed around 0.5 AU. In the presence of $20 \mu \mathrm{g} / \mathrm{ml} \mathrm{sGPC} 3 \mathrm{~m}$, we observed two populations distributed around 0.5 and $0.8 \mathrm{AU}$, and for $30 \mu \mathrm{g} / \mathrm{ml}$, a main population distributed around $0.6 \mathrm{AU}$ with a shoulder at 0.9-1.0 AU and two other minor peaks at 1.2 and 1.5 AU. The important rise in the nuclear particle area is consistent with an increase in the number of binucleated or polynucleated cells observed in the presence of sGPC3m (Figure 2B).
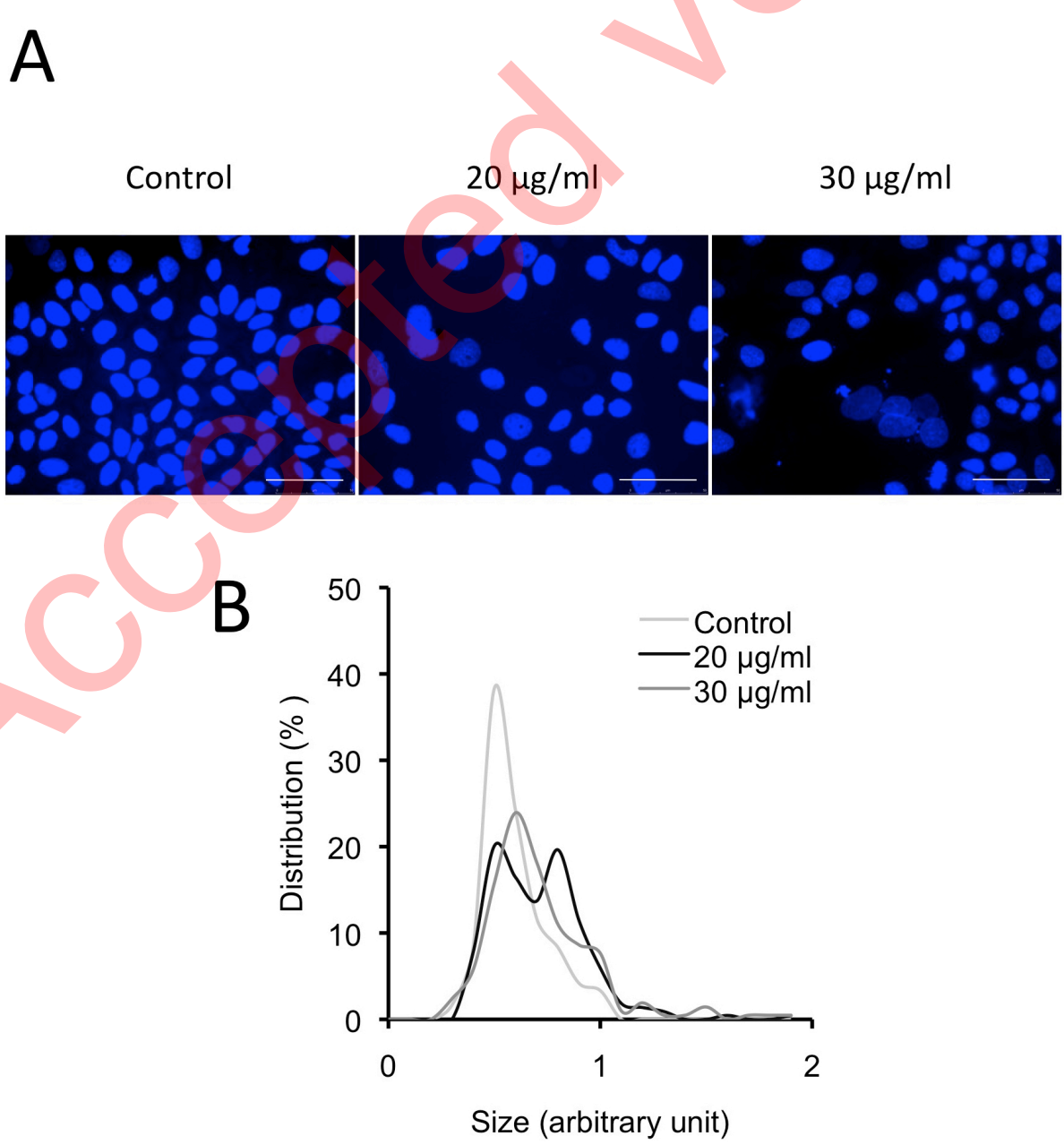

Figure 5: sGPC3m increases the nuclear DNA area. HuH7 cells $(20,000 / \mathrm{ml})$ were incubated for four days without (control) or with 20 or $30 \mu \mathrm{g} / \mathrm{ml} \mathrm{sGPC} 3 \mathrm{~m}$. A) After fixation, the nuclei 
were stained with Hoechst and the cells were photographed (40x magnification) under a fluorescence microscope. The white bar represents $50 \mu \mathrm{m}$. B) Fluorescent nuclei were analyzed as particles with ImageJ, and the area was expressed in arbitrary units (AU).

Unexpectedly, the sGPC $3 \mathrm{~m}$ treated cells did not undergo cell death. As can be seen in Figure 6A, after four days of growth, $\mathrm{HuH} 7$ cells behave similarly in the absence or presence of 20 $\mu \mathrm{g} / \mathrm{ml} \mathrm{sGPC} 3 \mathrm{~m}$. Indeed there was no increase in the number of cells entering necrosis or apoptosis and more than $95 \%$ of the analyzed cells remained viable in both cases. The same conclusion holds true for HepG2 cells (Figure 6B). The question arises as to whether the progression of the cell cycle was modified by sGPC $3 \mathrm{~m}$. The distribution of HuH7 and HepG2 cells in the cell cycle was similar, with or without added sGPC3m (Figure 6C and D), indicating that the proliferation inhibition did not result from cell cycle modification either.
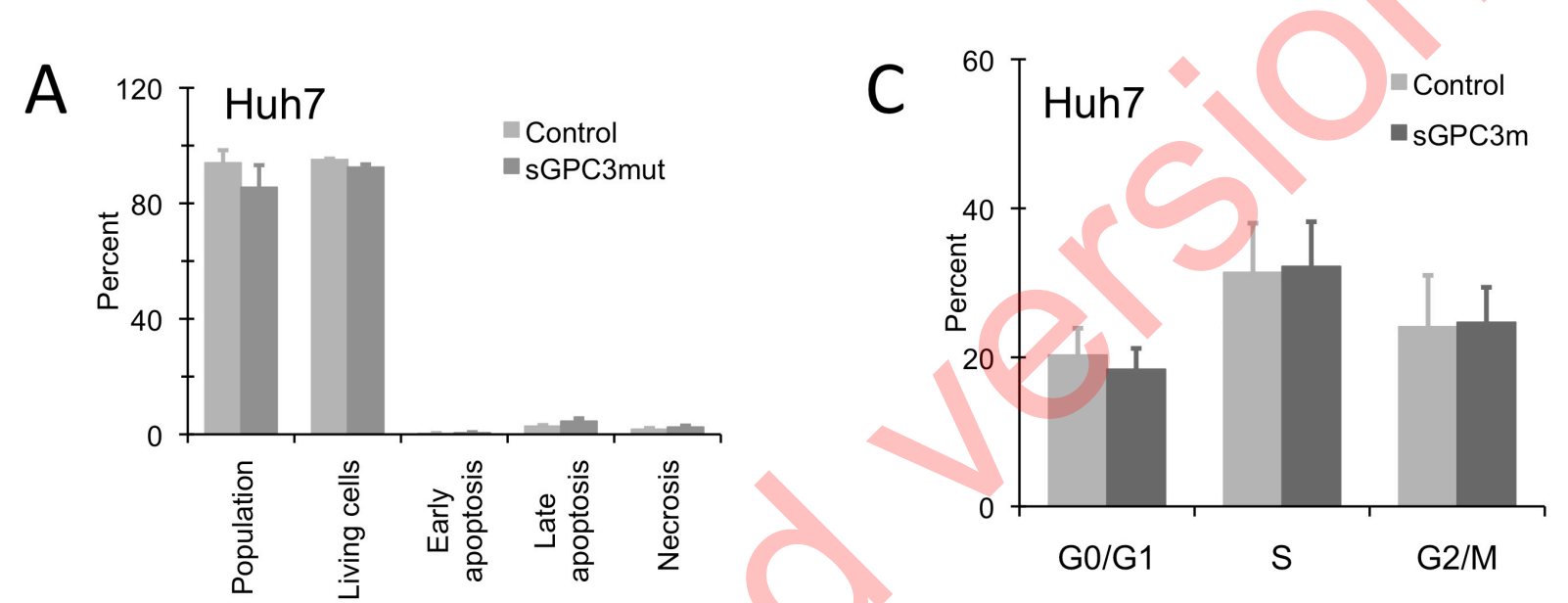

B

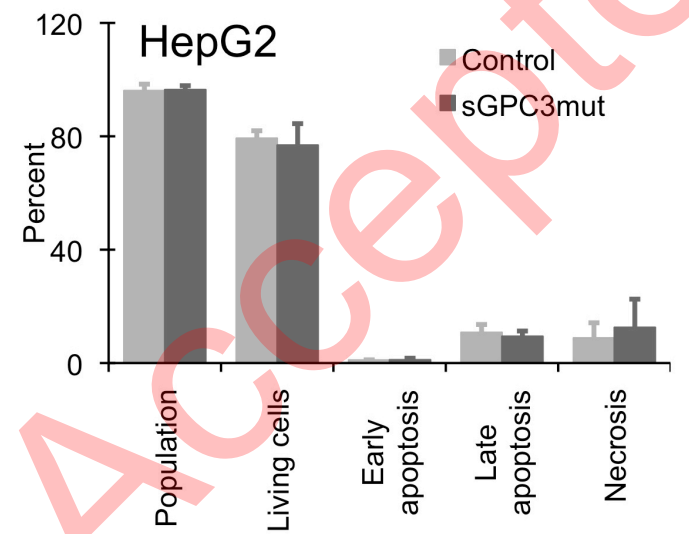

D

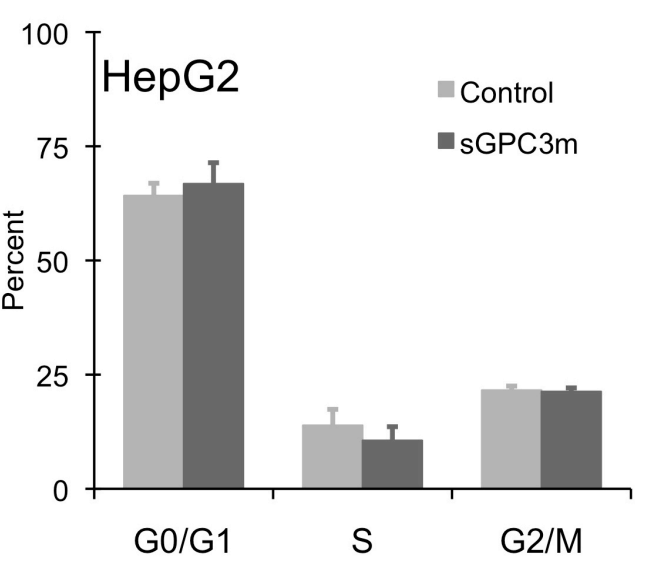

Figure 6: sGPC3m does not induce cell death or modify the cell cycles. HuH7 cells (A, C) or HepG 2 cells $(B, D)(50,000 / \mathrm{ml})$ were incubated for four days with $20 \mu \mathrm{g} / \mathrm{ml} \mathrm{sGPC} 3 \mathrm{~m}$. They were then processed by flow cytometry for apoptosis and necrosis analyses with the PE Annexin V Apoptosis Detection Kit I from BD Pharmingen (A, B) or cell cycle with the BrdU Flow kit from BD Pharmingen $(\mathrm{C}, \mathrm{D})$. Each result is representative of at least three independent experiments. 
sGPC3m inhibition could involve the Wnt/ $\beta$-catenin pathway in the HepG2 cells but not in the $\mathrm{HuH7}$ cells.

Soluble GPC3 inhibits the Wnt pathway in HuH6 and HuH7-derived tumors in mice but not in HepG2-derived tumors ${ }^{24}$. To evaluate this pathway in the presence of sGPC $3 \mathrm{~m}$, we analyzed the cell extracts from $\mathrm{HuH} 7$ and HepG2 cells incubated with $20 \mu \mathrm{g} / \mathrm{ml} \mathrm{sGPC} 3 \mathrm{~m}$ for four days by SDS-PAGE and western blotting. $\beta$-catenin was detected at similar levels as well as the mesenchymal marker fibronectin 1 (FN1), as exemplified in Figure 7A and B. These levels did not change either when $\mathrm{HuH} 7$ cells were incubated in the presence of 40 and $50 \mu \mathrm{g} / \mathrm{ml} \mathrm{sGPC} 3 \mathrm{~m}$ for 3, 4 and 5 days (data not shown). However, we could not reliably detect Wnt3a in the culture medium of HuH7 cells, whatever the conditions and duration of incubation (data not shown). The Wnt pathway was described as being not very active in these cells, which express a nonmutated form of $\beta$-catenin ${ }^{24}$. Thus, we propose that in the HuH7 cells the inhibitory effect of sGPC $3 \mathrm{~m}$ might not involve alteration of the $\mathrm{Wnt} / \beta$-catenin pathway. On the contrary, in the HepG2 cells, the level of Wnt3a in the culture medium increased with the sGPC $3 \mathrm{~m}$ concentration though the number of cells decreased due to proliferation inhibition (Figure 7C). The Wnt pathway was described as being very active in these cells, which contain a truncated and constitutively active form of $\beta$-catenin ${ }^{20}$. Our results suggest that the HepG2 cells were offsetting the Wnt pathway inhibition by adjusting the Wnt3a levels. This hypothesis is supported by the fact that the expression of the soluble GPC3 does not modify the Wnt pathway in HepG2 cells $^{24}$. Besides that, there was no difference in the Erk and Akt levels and phosphorylation status (Figure 7B). Noticeably, high levels of sGPC3m were detected in extracts of both cell types (Figure 7D). The endogenous GPC3 was barely detectable in the $\mathrm{HuH7}$ cells as opposed to what was observed for the HepG2 cells.

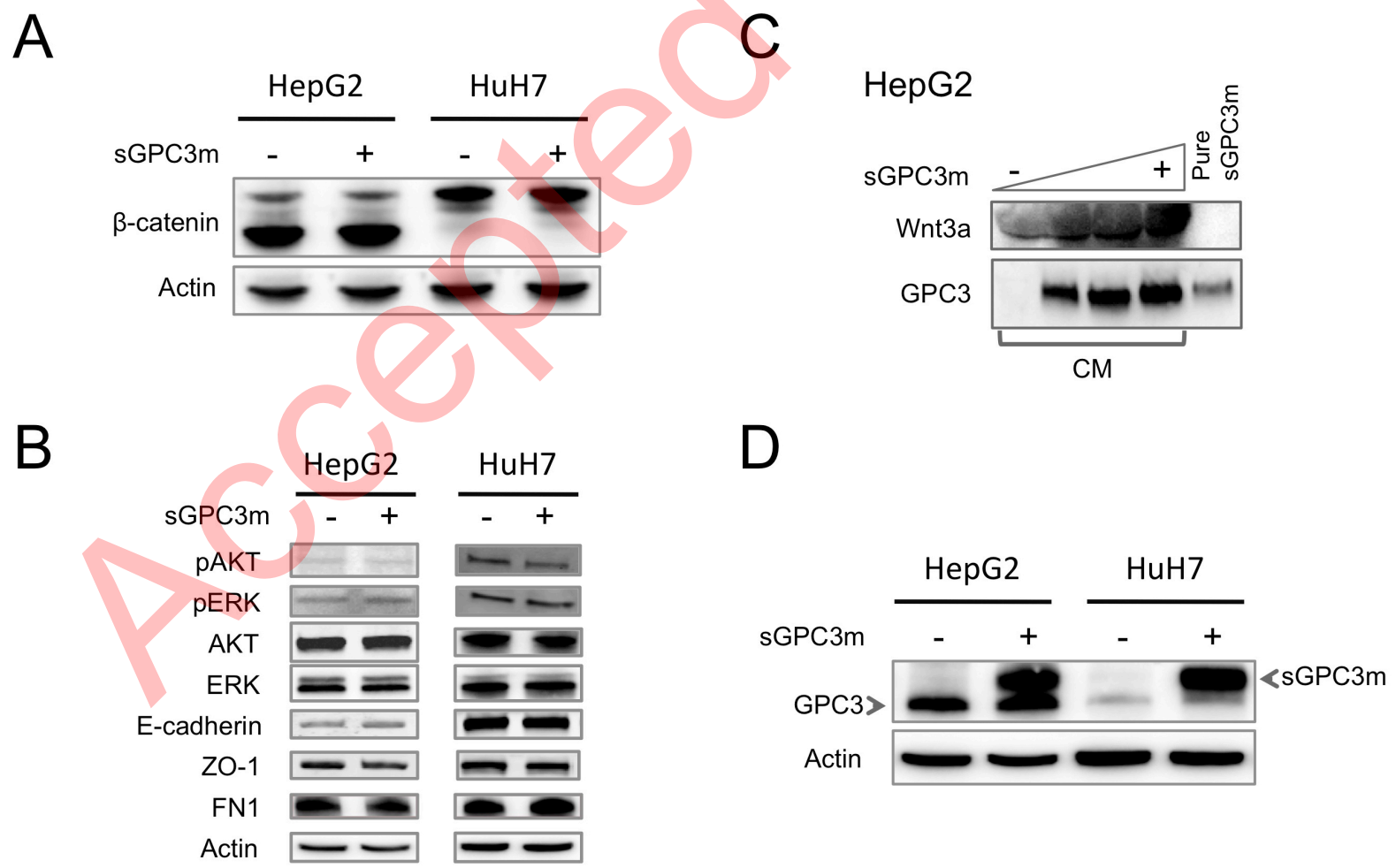

Figure 7: sGPC3mut inhibition could involve the Wnt/ $\beta$-catenin pathway in HepG2 cells but not in $\mathrm{HuH7}$ cells. A to $\mathrm{C}) \mathrm{HuH} 7$ cell extracts were analyzed by SDS-PAGE and immunoblotting, after 4 days of growth without (-) or with sGPC3mut (+). Total proteins were stained with SYPRO Ruby or Ponceau Red before immunodecoration with anti actin, B-catenin antibodies (A) or with anti phosphoAKT, phosphoERK, AKT, ERK, E-cadherin, ZO-1, or or 
FN1 antibodies (B) or anti GPC3 antibodies (D). Each result is representative of at least three independent experiments. C) The culture medium (CM) of HepG2 cells $(20,000 / \mathrm{ml})$ incubated with $0,10,20$ or $30 \mu \mathrm{g} / \mathrm{ml}$ sGPC3mut was analyzed after six days of growth by western blotting with antibodies directed against Wnt3a or GPC3. Pure sGPC3mut was loaded on the right lane.

The added sGPC3m had an electrophoretic mobility on SDS-PAGE different from that of the native GPC3, in line with the difference between their molecular masses. We analyzed the GPC3 location by confocal microscopy with an antibody directed against GPC3 (Figure 8). In the $\mathrm{HuH} 7$ control cells, it was mainly associated with the membranes while it was also observed within the cytoplasm of the HepG2 control cells. In the presence of sGPC $3 \mathrm{~m}$, the fluorescence labeling in the cytoplasm was highly increased for both cell types and fluorescent dots were noticed (Figure 8). These observations suggest an efficient uptake of sGPC $3 \mathrm{~m}$ by cells during culture. Our results do not demonstrate that sGPC $3 \mathrm{~m}$ is internalized by endocytosis or by a process involving a GPC3 specific receptor. However, it is reasonable to think that the absence of the GPI anchor precludes the tight binding of sGPC $3 \mathrm{~m}$ to the membranes. We propose that sGPC $3 \mathrm{~m}$ association with the plasma membrane could precede its uptake by a still unknown mechanism.

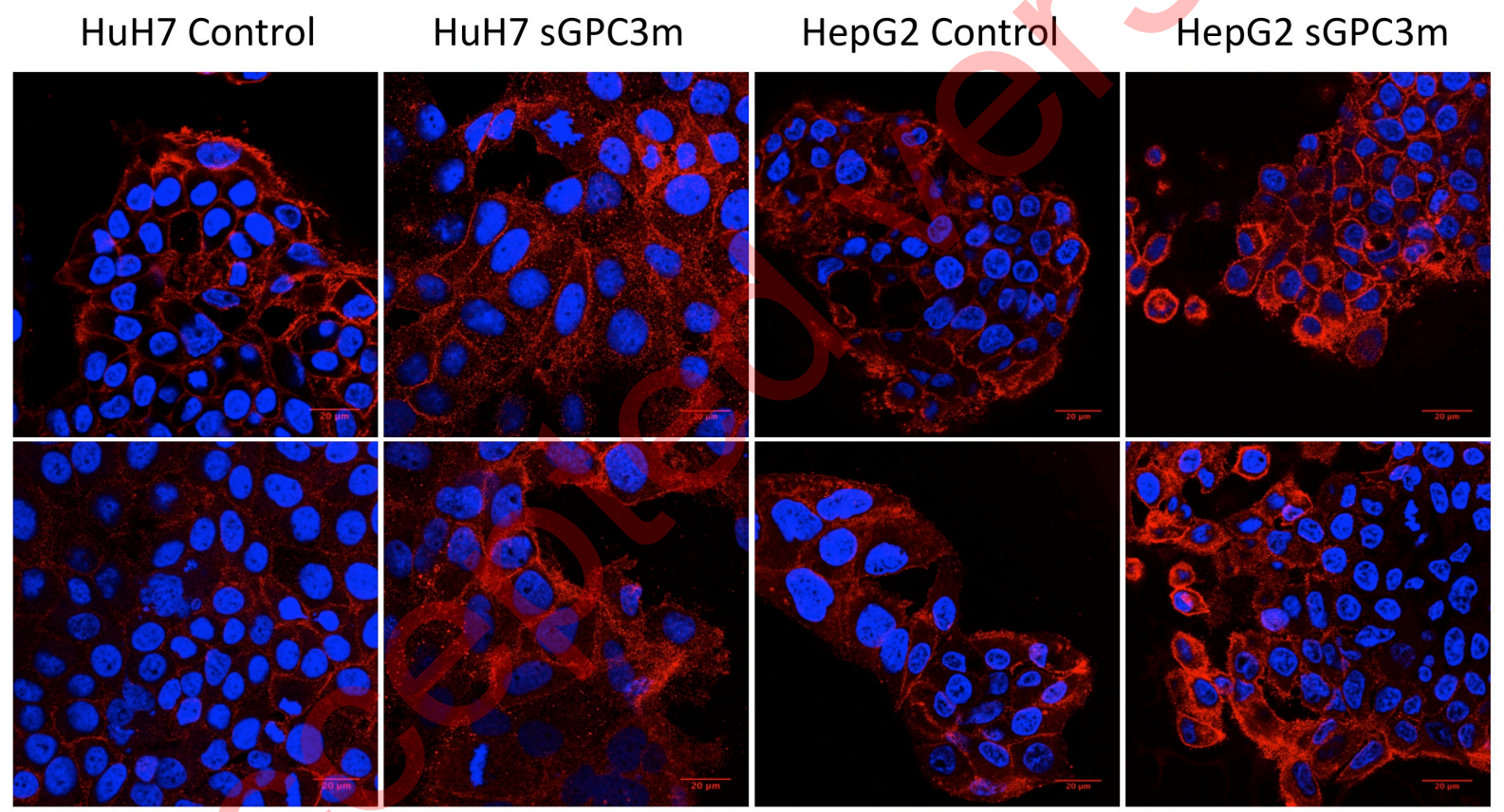

Figure 8: Subcellular localization of GPC3 and sGPC3m in hepatic cells incubated or not with sGPC $3 \mathrm{~m}$. HuH7 or HepG2 cells $(20,000 / \mathrm{ml})$ were seeded on sterile cover glasses without or with sGPC3m $(20 \mu \mathrm{g} / \mathrm{ml})$. After four days of growth, cells were stained with DAPI and antibodies against GPC3 (red).

\section{sGPC3m modifies the ZO-1 distribution within the HuH7 cell junctions}

According to a recent paper, cell migration and metastatic capacities of various HCC cells are proportional to the endogenous GPC 3 expression levels and can be increased by adding a soluble form of the fully glycanated GPC 3 outside the cells ${ }^{3}$. HepG 2 cells have higher migration and invasion capacities than $\mathrm{HuH} 7$ cells, which express much lower levels of GPC3 and higher levels of E-cadherin ${ }^{31}$. E-cadherin, $\beta$-catenin and the tight junction protein ZO-1 (or TJP1) are among the markers of epithelial cells. We first observed that the levels of these proteins were 
not modified by sGPC3m addition (Figure 7B), whatever the HCC cell type. We then analyzed their distributions by immunofluorescence. E-cadherin was expressed at the $\mathrm{HuH} 7$ cell junctions but also concentrated in spots in the cytoplasm and this was not modified by sGPC $3 \mathrm{~m}$ (data not shown). In the case of ZO-1, sGPC $3 \mathrm{~m}$ induced a disruption of its membranous location in favor of a more soluble distribution in $\mathrm{HuH7}$ cells (Figure 9A, white arrows point to examples). This could be linked to the decrease in the cell number and to the aberrant cell shapes, as observed in Figure $2 \mathrm{~B}$. To quantify these observations, we measured the total length of the ZO-1 network $(\mu \mathrm{m})$ and the surface of the DNA regions stained with DAPI $\left(\mu \mathrm{m}^{2}\right)$ with the Image J software for 8 photographs under each experimental condition. The normalized ratio ZO-1/DAPI $\left(\mu \mathrm{m} / \mu \mathrm{m}^{2}\right.$ or $\left.1 / \mu \mathrm{m}\right)$ in the presence of sGPC $3 \mathrm{~m}$ was half of the ratio in the absence (Figure 9C). If we take into account the 20-\% increase in the nuclear area size induced by sGPC 3m (Figure 5), the ZO-1/DAPI ratio is diminished by $40 \%$, which remains significant. These results reflected a clear decrease in the continuous ZO-1 network induced by sGPC $3 \mathrm{~m}$. In the case of the HepG2 cells, we observed no difference, induced sGPC3m, in the ZO-1 distribution, which was mainly cytoplasmic and not associated with the plasma membrane (Figure 9B).

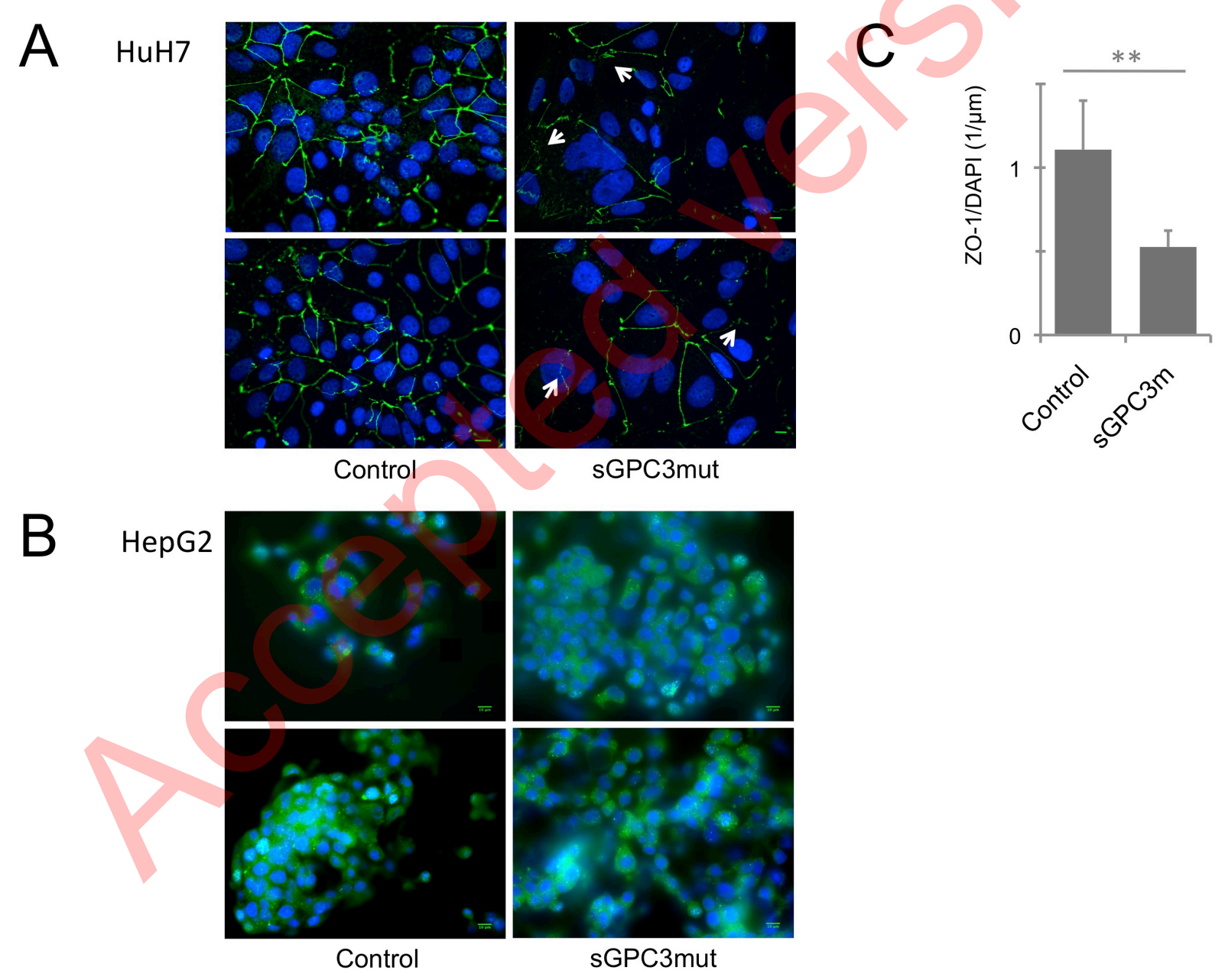

Figure 9: sGPC3m modifies the HuH7 cell junctions but not that of the HepG2 cells. HuH7 (A, C) or HepG2 cells (B) $(20,000 / \mathrm{ml})$ were seeded on sterile cover glasses without or with sGPC $3 \mathrm{~m}(20 \mu \mathrm{g} / \mathrm{ml})$. After four days of growth, cells were stained with DAPI and antibodies against ZO-1 (green) (A, B). White arrows indicate disruption of the ZO-1 network. C) The length $(\mu \mathrm{m})$ of the ZO-1 network and the surface of the nuclear area $\left(\mu \mathrm{m}^{2}\right)$ visualized by DAPI 
were measured with the ImageJ software for the HuH7 cells. The ZO-1/DAPI ratio was normalized to the values obtained for the control cells. ${ }^{* *}, \mathrm{p}<0.01$.

\section{DISCUSSION}

Tumoral progression is often associated with high expression of GPC3 in HCC cells and immunostaining shows that GPC3 localizes within the cytoplasm and also at the plasma membrane. The role of GPC3 in tumorigenesis is supported by the fact that its silencing by RNAi induces apoptosis in HepG2 cells ${ }^{32}$. Therefore GPC3 is considered as a powerful biomarker for both HCC diagnosis and prognostic as well as an interesting therapeutic target (see for examples ${ }^{16,1,1,1,1,9}$ ). Yet, a soluble form of GPC3, from which the GPI anchor was removed, can revert this tumorigenicity. Indeed, its ectopic expression inhibited HCC cell proliferation in vitro and in vivo ${ }^{24}$. Eventually, Feng et al ${ }^{25}$ used a partially purified GPC 3 and concluded that the soluble GPC3 protein itself played a role in HCC cell inhibition. Besides that, GPC3 undergoes several other PTM, whose roles vary with the GPC3 function and cellular context. Therefore, it was important to control these PTM. For this purpose, we designed a soluble mutant of GPC3 of which the HSGAG attachment sites were removed and the furin-like cleavage site was mutated.

We succeeded in obtaining a highly pure sGPC $3 \mathrm{~m}$ and confirmed the three $\mathrm{N}$-glycosylation sites previously hypothesized (Asn ${ }^{124}, \mathrm{Asn}^{241}$ and $\mathrm{Asn}^{418}$ ) as well as the $\mathrm{N}$-terminus of the mature protein $\left(\mathrm{Gln}^{25}\right)$, which appeared to be blocked by a pyroglutamic acid, due to the conversion of $\mathrm{Gln}^{25}$. Such a post-translational modification is present at the $\mathrm{N}$-terminus of numerous peptides and proteins (neuronal peptides, amyloid-beta peptides, hormones, antibodies...) ${ }^{33}$. Yet its biological role other than in ensuring protein stability against degradation by aminopeptidases is still poorly understood ${ }^{34}$. This modification could also arise from the conditions of sGPC $3 \mathrm{~m}$ production in the 293-F cells, as suggested for other proteins ${ }^{35}$. Therefore, we cannot conclude with regards to the biological relevance of this post-translational modification in the case of GPC3. The purified sGPC3m, whose convertase site was inactivated, exhibited the expected molecular mass. It underwent no degradation during storage at $4{ }^{\circ} \mathrm{C}$ for up to four months. This suggests the absence of a cryptic convertase site, unlike what was proposed for the glypican Dally-like ${ }^{13}$.

The proliferation inhibition properties of the highly purified sGPC $3 \mathrm{~m}$ were examined on two HCC cells. The generation times of $\mathrm{HuH} 7$ and HepG2 cells practically doubled upon the addition of $30 \mu \mathrm{g} / \mathrm{ml} \mathrm{sGPC} 3 \mathrm{~m}$. The proliferation inhibition was concentration-dependent with an apparent $\mathrm{IC}_{s 0}=8 \pm 2 \mu \mathrm{g} / \mathrm{ml}$ for $\mathrm{HuH} 7$ cells and around $16 \mu \mathrm{g} / \mathrm{ml}$ for HepG2 cells. Our results are in line with those of Feng et al.$^{25}$ who observed HepG2 cell growth inhibition with a partially purified soluble GPC3 with an $\mathrm{IC}_{50}$ of around $15 \mu \mathrm{g} / \mathrm{ml}$. We can conclude that the convertase and HSGAG modifications are not required for inhibiting HCC cell growth in vitro. We also observed that SGPC3m did not inhibit the transformed HEK293T cell proliferation (data not shown). In the case of the breast cancer cells MCF-7, the inhibition was moderate (around 30 $\%$ ) and almost disappeared after five days of incubation (data not shown). The role of glypicans in breast tumor progression is still debated and contradictory results were obtained regarding their expression ${ }^{3637}$. GPC3 down-regulation was described as responsible for some breast cancer development and GPC3 ectopic expression inhibited breast cancer cell growth ${ }^{38.99}$. These results suggest an antitumor role of GPC3. Obviously sGPC3m lacks one or more modifications to be an efficient anti-breast cancer agent, and tethering to the membrane by the GPI anchor could be the prerequisite.

We observed that externally added sGPC $3 \mathrm{~m}$ was partly associated with the cells, while another part remained stable in the growth medium. Daily renewal of sGPC $3 \mathrm{~m}$ increased growth inhibition similarly to daily addition. It seems that only those cells that did not bind 
sGPC 3m could escape inhibition. We can conclude that when sGPC3m was stably associated with HCC cells, either trapped at the plasma membrane or located within the cytoplasm, the inhibition was irreversible. The membranous location of sGPC $3 \mathrm{~m}$ probably precedes its uptake.

Deregulation of the canonical Wnt pathway has been described for various $\mathrm{HCC}^{23}$ and when soluble GPC 3 is ectopically expressed, it titrates Wnt3a, which was externally added to Hep3B and HepG2 cells ${ }^{24}$. Thus, we supposed that externally added sGPC $3 \mathrm{~m}$ would similarly titrate Wnt3a and inhibit the Wnt pathway. Interestingly, we observed an increase in Wnt3a expression for the HepG2 cells correlating with the concentration of added sGPC $3 \mathrm{~m}$. This suggests that these cells could be trying to overcome a possible Wnt pathway inhibition by overproducing Wnt3a. On the contrary, we could not detect Wnt3a expression for $\mathrm{HuH} 7$ cells and we observed no variation of the intracellular level of $\beta$-catenin, which is of the wild type in these cells. We can suggest that added sGPC3m does not dramatically modify the canonical Wnt pathway for the $\mathrm{HuH} 7$ cells. In line with our results, Zitterman and al ${ }^{24}$ hypothesized that this pathway is not very active in HuH7-derived tumors. Several other signaling pathways are aberrantly activated in HCC such as EGF and HGF pathways. However, sGPC3m did not modify the status of Erk and Akt phosphorylation, unlike what was observed with the ectopic expression of sGPC $3^{24}$. One possible reason is that these growth factors bind to GPC 3 through its HSGAG chains and they were removed in our studies. Investigating this hypothesis requires the construction of another mutant GPC3 with a different tag. This approach is currently under consideration, as well as global transcriptome and proteome analyses to identify targets of sGPC3m and understand more in depth its inhibitory properties.

The convertase processing is not mandatory for membrane tethered GPC 3 to stimulate HCC cell proliferation ${ }^{22}$ and our results clearly show that it is not necessary either for soluble GPC3 to inhibit HCC cell proliferation, at least in the absence of HSGAG addition. On the other hand, convertase processing is required for GPC3 to modulate the Wnt or Hedgehog signaling pathways or cell survival of non-HCC cell lines ${ }^{21+40}$. This could explain why we did not observe variation of the beta-catenin contents of HCC cells, and possibly of the Wnt patway, upon incubation with sGPC $3 \mathrm{~m}$.

sGPC $3 \mathrm{~m}$ induced changes in the HuH7 cell morphology associated with a significant increase in nuclear DNA area. However, the levels of apoptotic and necrotic cells were not modified by the addition of sGPC $3 \mathrm{~m}$ for both HCC cell types examined. The progression of the cell cycle was not modified either, supporting the idea that the main sGPC $3 \mathrm{~m}$ effect was lengthening of the HCC cell generation time after tight association with the cells. The presence of the HSGAG and/or the convertase maturation process appears to play a critical role in inducing cell death. We can propose that the lack of negative charges prevents sGPC $3 \mathrm{~m}$ binding to specific receptors at the cell surface, and this could be necessary to elicit cell death.

HuH7 cells are epithelial-like and as such tightly joined. When investigating different markers of the epithelial-mesenchymal transition (EMT), such as E-cadherin and ZO-1, we observed no modification of their expressions. However, the tight junction protein ZO-1 is differently organized around $\mathrm{HuH} 7$ cells in the presence of sGPC $3 \mathrm{~m}$. This may be related to the poorer proliferation of the $\mathrm{HuH} 7$ cells resulting in an increase in the generation time and in the nuclear area. The unchanged levels of E-cadherin or ZO-1 suggest that sGPC 3m does not induce EMT and therefore metastatic capabilities.

In conclusion, the mutant GPC3 we designed and produced inhibits efficiently and specifically HCC cell proliferation by increasing the generation time in vitro. Clearly, we show that the convertase maturation and the HSGAG addition are dispensable to this effect. However, they seem to be crucial for the cells to enter cell death. The high degree of purity of sGPC $3 \mathrm{~m}$ preparation has allowed us to undertake structural studies (paper in preparation), which will shed light on the structure of GPC3 and open the way to the understanding of the differences between the various members of the glypican family at an atomistic level and to the design of 
inhibiting peptides. Indeed, so far GPC3-based immunotherapy, though promising, has failed to improve significantly patient survival ${ }^{19}$ and there is still a crucial need of efficient treatments against HCC.

\section{AUTHOR INFORMATION}

\section{Corresponding Author}

*Véronique Trézéguet MiRCaDE, BMGIC U1035, Bât 3b, 1Et, 146 rue Léo Saignat, F-33076, Bordeaux cedex, France. Mail: veronique.trezeguet-busquet@ u-bordeaux.fr. Tel: +33 (0)557 571541 .

\section{Present Addresses}

†UMR CNRS-UGA 5250, ICMG FR-2607, Université Genoble Alpes - Bâtiment NanoBio, Campus, 570, rue de la Chimie, BP53, 38041 Grenoble cedex 9, France

\section{Author Contributions}

The manuscript was written through contributions of all authors. All authors have given approval to the final version of the manuscript. $\ddagger$ These authors contributed equally.

\section{Funding Sources}

This work was supported by Le Canceropôle Grand Sud-Ouest, La Ligue Contre le Cancer, l'Institut National du Cancer (INCa project INCa_5828/INCa_PLBIO_2012_110), the CNRS, INSERM and Bordeaux University.

\section{Notes}

This paper is dedicated to the memory of Bernard Gallois who suddenly passed away. We are grateful for his support during the development of the experiments described therein.

\section{ACKNOWLEDGMENT}

We are grateful to Jorge Filmus for his help to initiate this work and to Anne-Aurélie Raymond and Hélèna Fazli for their technical help.

\section{ABBREVIATIONS}

ß-cat: beta-catenin; Cadh: cadherin; EMT, epithelial-mesenchymal transition; FN1: Fibronectin 1; GPC3: Glypican 3; GPI: Glycosylphosphatidylinositol; HCC: Hepatocellular Carcinoma; HSGAG: Heparan-Sulfate Glycosaminoglycan; PTM, post-translational modification; sGPC3m: Soluble mutant GPC3; ZO-1: Tight Junction Protein ZO-1.

\section{SUPPORTING INFORMATION}

Glycan composition determined by Byonic and $\mathrm{HuH} 7$ cell proliferation.

\section{REFERENCES}

(1) Filmus, J., and Capurro, M. (2008) The role of glypican-3 in the regulation of body size and cancer. Cell Cycle 7, 2787-2790.

(2) Filmus, J., and Selleck, S. B. (2001) Glypicans: proteoglycans with a surprise. J. Clin. Invest. 108, 497-501.

(3) Jakubovic, B. D., and Jothy, S. (2007) Glypican-3: from the mutations of Simpson-Golabi-Behmel genetic syndrome to a tumor marker for hepatocellular carcinoma. Exp. Mol. Pathol. 82, 184-189.

(4) Allegretta, M., and Filmus, J. (2011) Therapeutic potential of targeting glypican-3 in hepatocellular carcinoma. Anticancer Agents Med Chem 11, 543-548. 
(5) Ho, M., and Kim, H. (2011) Glypican-3: a new target for cancer immunotherapy. Eur. J. Cancer 47, 333-338.

(6) Fico, A., Maina, F., and Dono, R. (2011) Fine-tuning of cell signaling by glypicans. Cell. Mol. Life Sci. 68, 923-929.

(7) Iglesias, B. V., Centeno, G., Pascuccelli, H., Ward, F., Peters, M. G., Filmus, J., Puricelli, L., and de Kier Joffé, E. B. (2008) Expression pattern of glypican-3 (GPC3) during human embryonic and fetal development. Histol. Histopathol. 23, 1333-1340.

(8) Hsu, H. C., Cheng, W., and Lai, P. L. (1997) Cloning and expression of a developmentally regulated transcript MXR7 in hepatocellular carcinoma: biological significance and temporospatial distribution. Cancer Res. 57, 5179-5184.

(9) Zhou, X.-P., Wang, H.-Y., Yang, G.-S., Chen, Z.-J., Li, B.-A., and Wu, M.-C. (2000) Cloning and expression of MXR7 gene in human HCC tissue. World J. Gastroenterol. 6, 57-60.

(10) Zhu, Z. W., Friess, H., Wang, L., Abou-Shady, M., Zimmermann, A., Lander, A. D., Korc, M., Kleeff, J., and Büchler, M. W. (2001) Enhanced glypican-3 expression differentiates the majority of hepatocellular carcinomas from benign hepatic disorders. Gut 48, 558-564.

(11) Midorikawa, Y., Ishikawa, S., Iwanari, H., Imamura, T., Sakamoto, H., Miyazono, K., Kodama, T., Makuuchi, M., and Aburatani, H. (2003) Glypican-3, overexpressed in hepatocellular carcinoma, modulates FGF2 and BMP-7 signaling. Int. J. Cancer 103, 455-465.

(12) Satoh, S., Daigo, Y., Furukawa, Y., Kato, T., Miwa, N., Nishiwaki, T., Kawasoe, T., Ishiguro, H., Fujita, M., Tokino, T., Sasaki, Y., Imaoka, S., Murata, M., Shimano, T., Yamaoka, Y., and Nakamura, Y. (2000) AXIN1 mutations in hepatocellular carcinomas, and growth suppression in cancer cells by virus-mediated transfer of AXIN1. Nat. Genet. 24, 245-250.

(13) Kim, M.-S., Saunders, A. M., Hamaoka, B. Y., Beachy, P. A., and Leahy, D. J. (2011) Structure of the protein core of the glypican Dally-like and localization of a region important for hedgehog signaling. Proc. Natl. Acad. Sci. U.S.A. 108, 13112-13117.

(14) Feitelson, M. A., Sun, B., Satiroglu Tufan, N. L., Liu, J., Pan, J., and Lian, Z. (2002) Genetic mechanisms of hepatocarcinogenesis. Oncogene 21, 2593-2604.

(15) Thompson, M. D., and Monga, S. P. S. (2007) WNT/beta-catenin signaling in liver health and disease. Hepatology 45, 1298-1305.

(16) Wang, L., Yao, M., Pan, L.-H., Qian, Q., and Yao, D.-F. (2015) Glypican-3 is a biomarker and a therapeutic target of hepatocellular carcinoma. HBPD INT 14, 361-366.

(17) Kaseb, A. O., Hassan, M., Lacin, S., Abdel-Wahab, R., Amin, H. M., Shalaby, A., Wolff, R. A., Yao, J., Rashid, A., Vennapusa, B., Feng, J., and Ohtomo, T. (2016) Evaluating clinical and prognostic implications of Glypican-3 in hepatocellular carcinoma. Oncotarget 7, 69916-69926.

(18) Haruyama, Y., and Kataoka, H. (2016) Glypican-3 is a prognostic factor and an immunotherapeutic target in hepatocellular carcinoma. World J. Gastroenterol. 22, 275-283.

(19) Llovet, J. M., Villanueva, A., Lachenmayer, A., and Finn, R. S. (2015) Advances in targeted therapies for hepatocellular carcinoma in the genomic era. Nat Rev Clin Oncol 12, 408-424.

(20) Svensson, G., Awad, W., Håkansson, M., Mani, K., and Logan, D. T. (2012) Crystal structure of $\mathrm{N}$-glycosylated human glypican-1 core protein: structure of two loops evolutionarily conserved in vertebrate glypican-1. J. Biol. Chem. 287, 14040-14051.

(21) De Cat, B., Muyldermans, S.-Y., Coomans, C., Degeest, G., Vanderschueren, B., Creemers, J., Biemar, F., Peers, B., and David, G. (2003) Processing by proprotein convertases is required for glypican-3 modulation of cell survival, Wnt signaling, and gastrulation movements. J. Cell Biol. 163, 625-635.

(22) Capurro, M. I., Shi, W., Sandal, S., and Filmus, J. (2005) Processing by convertases is not required for glypican-3-induced stimulation of hepatocellular carcinoma growth. J. Biol. Chem. 280, 4120141206

(23) Capurro, M. I., Xiang, Y.-Y., Lobe, C., and Filmus, J. (2005) Glypican-3 promotes the growth of hepatocellular carcinoma by stimulating canonical Wnt signaling. Cancer Res. 65, 6245-6254.

(24) Zittermann, S. I., Capurro, M. I., Shi, W., and Filmus, J. (2010) Soluble glypican 3 inhibits the growth of hepatocellular carcinoma in vitro and in vivo. Int. J. Cancer 126, 1291-1301.

(25) Feng, M., Kim, H., Phung, Y., and Ho, M. (2011) Recombinant soluble glypican 3 protein inhibits the growth of hepatocellular carcinoma in vitro. Int. J. Cancer 128, 2246-2247. 
(26) Maurel, M., Jalvy, S., Ladeiro, Y., Combe, C., Vachet, L., Sagliocco, F., Bioulac-Sage, P., Pitard, V., Jacquemin-Sablon, H., Zucman-Rossi, J., Laloo, B., and Grosset, C. F. (2013) A functional screening identifies five microRNAs controlling glypican-3: role of miR-1271 down-regulation in hepatocellular carcinoma. Hepatology 57, 195-204.

(27) Laloo, B., Simon, D., Veillat, V., Lauzel, D., Guyonnet-Duperat, V., Moreau-Gaudry, F., Sagliocco, F., and Grosset, C. (2009) Analysis of post-transcriptional regulations by a functional, integrated, and quantitative method. Mol. Cell Proteomics 8, 1777-1788.

(28) Pace, C. N., Vajdos, F., Fee, L., Grimsley, G., and Gray, T. (1995) How to measure and predict the molar absorption coefficient of a protein. Protein Sci. 4, 2411-2423.

(29) Hippo, Y., Watanabe, K., Watanabe, A., Midorikawa, Y., Yamamoto, S., Ihara, S., Tokita, S., Iwanari, H., Ito, Y., Nakano, K., Nezu, J., Tsunoda, H., Yoshino, T., Ohizumi, I., Tsuchiya, M., Ohnishi, S., Makuuchi, M., Hamakubo, T., Kodama, T., and Aburatani, H. (2004) Identification of soluble NH2terminal fragment of glypican-3 as a serological marker for early-stage hepatocellular carcinoma. Cancer Res. 64, 2418-2423.

(30) de La Coste, A., Romagnolo, B., Billuart, P., Renard, C. A., Buendia, M. A., Soubrane, O., Fabre, M., Chelly, J., Beldjord, C., Kahn, A., and Perret, C. (1998) Somatic mutations of the beta-catenin gene are frequent in mouse and human hepatocellular carcinomas. Proc. Natl. Acad. Sci. U.S.A. 95, 88478851.

(31) Wu, Y., Liu, H., Weng, H., Zhang, X., Li, P., Fan, C.-L., Li, B., Dong, P.-L., Li, L., Dooley, S., and Ding, H.-G. (2015) Glypican-3 promotes epithelial-mesenchymal transition of hepatocellular carcinoma cells through ERK signaling pathway. Int. J. Oncol.46, 1275-1285.

(32) Qi, X.-H., Wu, D., Cui, H.-X., Ma, N., Su, J., Wang, Y.-T., and Jiang, Y.-H. (2014) Silencing of the glypican-3 gene affects the biological behavior of human hepatocellular carcinoma cells. Mol Med Rep 10,3177-3184.

(33) Kumar, A., and Bachhawat, A. K. (2012) Pyroglutamic acid: throwing light on a lightly studied metabolite. Current Science 102, 288-297.

(34) Lai, Z. W., Petrera, A., and Schilling, O. (2015) Protein amino-terminal modifications and proteomic approaches for N-terminal profiling. Curr Opin Chem Biol 24, 71-79.

(35) Gramer, M. J. (2014) Product quality considerations for mammalian cell culture process development and manufacturing. Adv. Biochem. Eng. Biotechnol. 139, 123-166.

(36) Matsuda, K., Maruyama, H., Guo, F., Kleeff, J., Itakura, J., Matsumoto, Y., Lander, A. D., and Korc, M. (2001) Glypican-1 is overexpressed in human breast cancer and modulates the mitogenic effects of multiple heparin-binding growth factors in breast cancer cells. Cancer Res. 61, 5562-5569.

(37) Fernández-Vega, I., García, O., Crespo, A., Castañón, S., Menéndez, P., Astudillo, A., and Quirós, L. M. (2013) Specific genes involved in synthesis and editing of heparan sulfate proteoglycans show altered expression patterns in breast cancer. BMC Cancer 13, 24.

(38) Peters, M. G., Farías, E., Colombo, L., Filmus, J., Puricelli, L., and Bal de Kier Joffé, E. (2003) Inhibition of invasion and metastasis by glypican-3 in a syngeneic breast cancer model. Breast Cancer Res. Treat. 80, 221-232.

(39) Xiang, Y. Y., Ladeda, V., and Filmus, J. (2001) Glypican-3 expression is silenced in human breast cancer. Oncogene 20, 7408-7412.

(40) Capurro, M., Shi, W., Izumikawa, T., Kitagawa, H., and Filmus, J. (2015) Processing by convertases is required for glypican-3-induced inhibition of Hedgehog signaling. J. Biol. Chem. 290, 7576-7585. 
TOC illustration

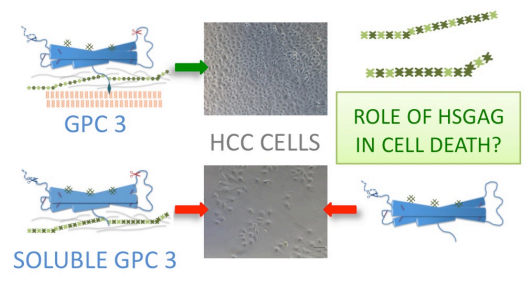


Supplementary information

Role of glycanation and convertase maturation of the soluble Glypican-3 in inhibiting proliferation of hepatocellular carcinoma cells

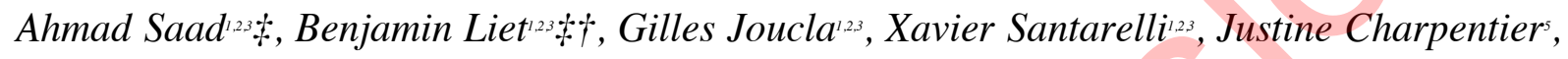
Stéphane Claverol, Christophe F. Grosset ${ }^{5,6}$, Véronique Trézéguet ${ }^{1,2,3 *}$

Univ. Bordeaux, CBMN, UMR 5248, F-33615, Pessac, France

${ }^{2} \mathrm{CNRS}$, CBMN, UMR 5248, F-33615, Pessac, France

${ }^{3}$ Bordeaux INP, CBMN, UMR 5248, F-33615, Pessac, France

${ }^{4}$ Univ. Bordeaux, Plateforme Protéome, CGFB, F-33076 Bordeaux, France

¿Univ. Bordeaux, Inserm, BMGIC, U1035, 33076 Bordeaux, France

'Univ. Bordeaux, Inserm, GREF, U1053, 33076 Bordeaux, France 


\begin{tabular}{|c|c|c|c|c|}
\hline 0Site & Peptide & Enzyme & Glycan & Byonic Score \\
\hline N124 & [R].HAKNYTNAMFK.[N] & Tryspin & HexNAc(1)Fuc(1) & 419 \\
\hline N124 & [R].HAKNYTNAMFK.[N] & Tryspin & $\operatorname{HexNAc}(5) \operatorname{Hex}(4) \operatorname{Fuc}(1)$ & 329 \\
\hline N124 & [R].HAKNYTNAMFK.[N] & Tryspin & $\operatorname{HexNAc}(4) H e x(5) F u c(1) N e u A c(1)$ & 280 \\
\hline N124 & [R].HAKNYTNAMFK.[N] & Tryspin & $\operatorname{HexNAc}(5) \operatorname{Hex}(4) \mathrm{Fuc}(1) \operatorname{NeuAc}(1)$ & 197 \\
\hline N124 & [R].HAKNYTNAMFK.[N] & Tryspin & $\operatorname{HexNAc}(4) \operatorname{Hex}(5) \operatorname{Fuc}(4)$ & 124 \\
\hline N124 & [R].HAKNYTNAMFK.[N] & Tryspin & 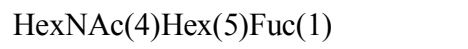 & 130 \\
\hline N124 & [R].HAKNYTNAMFK.[N] & Tryspin & $\operatorname{HexNAc}(6) \operatorname{Hex}(3) \operatorname{Fuc}(1)$ & 129 \\
\hline N124 & [R].HAKNYTNAMFK.[N] & Tryspin & HexNAc(5)Hex(4)Fuc(2)NeuGc(1) & 117 \\
\hline N124 & [F].EIVVRHAKNY.[T] & Chymotryspin & HexNAc(5)Hex(5)Fuc(1)NeuAc(1) & 182 \\
\hline N124 & [F].EIVVRHAKNY.[T] & Chymotryspin & $\operatorname{HexNAc}(5) H e x(4) F u c(2) N e u A c(1)$ & 161 \\
\hline N124 & [F].EIVVRHAKNY.[T] & Chymotryspin & $\operatorname{HexNAc}(6) \operatorname{Hex}(3) \mathrm{Fuc}(1) \mathrm{NeuAc}(1)$ & 228 \\
\hline N124 & [F].EIVVRHAKNY.[T] & Chymotryspin & HexNAc(4)Hex(5)Fuc(2)NeuAc(1) & 107 \\
\hline N124 & {$[\mathrm{F}] . E I V V R H A K N Y .[T]$} & Chymotryspin & $\operatorname{HexNAc}(5) \operatorname{Hex}(4) \operatorname{Fuc}(2)$ & 182 \\
\hline N124 & {$[\mathrm{F}] . E I V V R H A K N Y .[T]$} & Chymotryspin & $\operatorname{HexNAc}(5) \operatorname{Hex}(5) \mathrm{Fuc}(1)$ & 117 \\
\hline N241 & [I].NTTDHL.[K] & Elastase & $\operatorname{HexNAc}(4) \operatorname{Hex}(3) \operatorname{Fuc}(1)$ & 118 \\
\hline N241 & [I].NTTDHL.[K] & Elastase & $\operatorname{HexNAc}(4) H e x(4) F u c(2)$ & 115 \\
\hline N241 & [I].NTTDHL.[K] & Elastase & HexNAc(4)Hex(4)Fuc(2)NeuGc(1) & 193 \\
\hline N241 & [I].NTTDHL.[K] & Elastase & $\operatorname{HexNAc}(4) \operatorname{Hex}(5) \operatorname{Fuc}(1)$ & 119 \\
\hline N241 & [I].NTTDHL.[K] & Elastase & $\operatorname{HexNAc(4)Hex(5)Fuc(2)~}$ & 121 \\
\hline N241 & [I].NTTDHL.[K] & Elastase & HexNAc(4)Hex(5)Fuc(2)NeuAc(1) & 121 \\
\hline N241 & [I].NTTDHL.[K] & Elastase & $\operatorname{HexNAc}(4) H e x(5) F u c(3)$ & 123 \\
\hline N241 & [I].NTTDHL.[K] & Elastase & $\operatorname{HexNAc}(4) H e x(6) F u c(3)$ & 171 \\
\hline $\mathrm{N} 241$ & [I].NTTDHL.[K] & Elastase & HexNAc(5)Hex(4)Fuc(1) & 267 \\
\hline $\mathrm{N} 241$ & [I].NTTDHL.[K] & Elastase & HexNAc(5)Hex(4)Fuc(1)NeuAc(1) & 310 \\
\hline N241 & [I].NTTDHL.[K] & Elastase & HexNAc(5)Hex(4)Fuc(1)NeuAc(2) & 121 \\
\hline N241 & [I].NTTDHL.[K] & Elastase & HexNAc(5)Hex(4)Fuc(1)NeuGc(1) & 142 \\
\hline $\mathrm{N} 241$ & [I].NTTDHL.[K] & Elastase & HexNAc(5)Hex(4)Fuc(2) & 224 \\
\hline N241 & [I].NTTDHL.[K] & Elastase & $\operatorname{HexNAc}(5) H e x(4) F u c(2) N e u A c(1)$ & 251 \\
\hline N241 & [I].NTTDHL.[K] & Elastase & $\operatorname{HexNAc}(5) \operatorname{Hex}(4) \mathrm{NeuAc}(1)$ & 152 \\
\hline N241 & [I].NTTDHL.[K] & Elastase & $\operatorname{HexNAc(5)Hex(5)Fuc(1)~}$ & 125 \\
\hline N241 & [I].NTTDHL.[K] & Elastase & $\operatorname{HexNAc}(5) \operatorname{Hex}(5) \mathrm{Fuc}(1) \mathrm{NeuAc}(1)$ & 187 \\
\hline N241 & [I].NTTDHL.[K] & Elastase & $\operatorname{HexNAc}(5) \operatorname{Hex}(5) \operatorname{Fuc}(2)$ & 166 \\
\hline $\mathrm{N} 241$ & [I].NTTDHL.[K] & Elastase & $\operatorname{HexNAc}(5) \operatorname{Hex}(5) \operatorname{Fuc}(3)$ & 129 \\
\hline N241 & [I].NTTDHL.[K] & Elastase & $\operatorname{HexNAc}(6) \operatorname{Hex}(3) \mathrm{Fuc}(1) \mathrm{NeuAc}(1)$ & 108 \\
\hline N241 & [I].NTTDHL.[K] & Elastase & $\operatorname{HexNAc}(6) \operatorname{Hex}(3) \operatorname{Fuc}(2)$ & 117 \\
\hline N241 & [I].NTTDHL.[K] & Elastase & $\operatorname{HexNAc}(6) \operatorname{Hex}(3) \operatorname{Fuc}(3)$ & 143 \\
\hline N241 & [I].NTTDHL.[K] & Elastase & $\operatorname{HexNAc}(7) \operatorname{Hex}(6)$ & 118 \\
\hline N241 & [V].INTTDHL.[K] & Elastase & HexNAc(2)Hex(9) & 132 \\
\hline N418 & [E].NDTLCWNGQE.[L] & GluC & $\operatorname{HexNAc}(5) \operatorname{Hex}(4) \mathrm{Fuc}(2) \mathrm{NeuAc}(1)$ & 130 \\
\hline N418 & [P].VAENDT.[L] & Thermolysin & $\operatorname{HexNAc}(5) \operatorname{Hex}(4) \operatorname{Fuc}(2)$ & 188 \\
\hline N418 & [P].VAENDT.[L] & Thermolysin & HexNAc(5)Hex(4)Fuc(1)NeuAc(1) & 140 \\
\hline
\end{tabular}

Table S1: Glycan composition determined by Byonic. The search engine compares MS/MS from intact glycopeptides against a database consisting of 309 glycan structures commonly found among mammals. Only glycopeptides with Byonic score higher than 100 are shown. Peptide sequences and used proteases are also indicated. All three potential $N$-glycosylation sites are found glycosylated. 


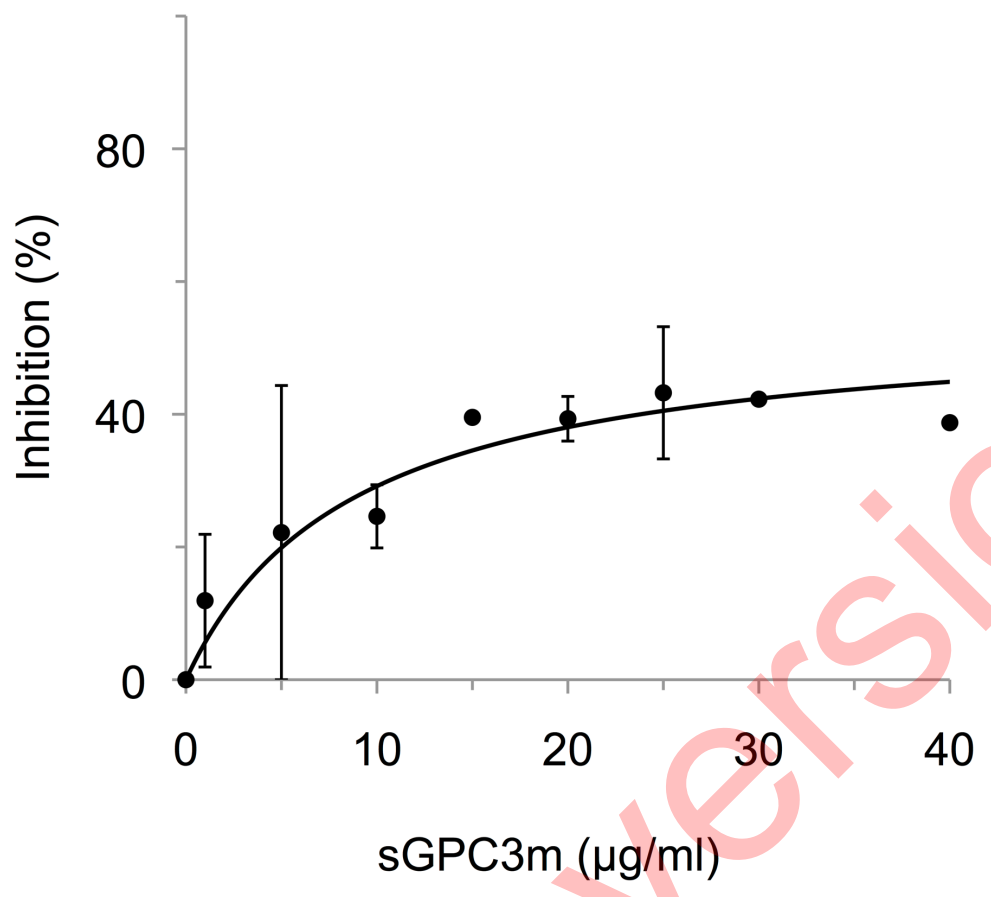

Figure S1: Inhibition of HuH7 cell proliferation by sGPC3m. HuH7 cells $(20,000-50,000 / \mathrm{ml})$ were incubated for two days at $37^{\circ} \mathrm{C}, 5 \% \mathrm{CO} 2$ with variable amounts of sGPC $3 \mathrm{~m}$ (0 to 40 $\mu \mathrm{g} / \mathrm{ml}$ ). 